\title{
Optik Renk Karışımı ve Resim Restorasyonunda Tamamlama Yöntemleri
}

\section{Optical Color Mixing and Reintegration Methods on Painting Restoration}

Ezgin Yetiș, Sanat Eserleri Konservasyonu ve Restorasyon Bölümü, Kastamonu Üniversitesi Berna Çağlar Eryurt, Kültür Varlıklarını Koruma ve Onarım Bölümü, Ankara Hacı Bayram Veli Üniversitesi Bekir Eskici, Kültür Varlıklarını Koruma ve Onarım Bölümü, Ankara Hacı Bayram Veli Üniversitesi

\begin{abstract}
Özet
Öncelikle kültürel mirasımızın önemli bir grubunu oluşturan resimler; arkeolojik alanlardan müzelere, özel koleksiyonlardan mimari yapılara kadar panel, kanvas, duvar ve çeșitli diğer tașıyıcı malzemeler üzerinde yer almaktadır. Bunların korunması için niteliklerine ve ortaya koydukları korunma durumlarına göre çeșitli yöntemler uygulanır. Koruma uygulamalarında en çok tartışılan konuların bașında resimlerin artistik değerini ve ikonografik okunurluğunu arttırmak için yapılan tamamlamaya dönük müdahaleler gelir. Ancak bunlar resimlerin korunması için hayati bir ihtiyaç değildir. Daha çok kozmetik müdahale niteliği tașıyan bu tür uygulamalar, izleyici için eserin sunumu ile ilgili problemlere odaklanan estetik gereklilik olarak ortaya cıkmaktadır. Bu gereklilik 19. yüzyılın sonlarından itibaren farklı teknik, yöntem ve malzemelerin tartıșılarak uygulandığı çalıșmaları beraberinde getirmiş; farklı yaklaşımlar geliştirilmiştir.
\end{abstract}

Calıșmada; renk teorisinin gelișimi ile birlikte, koruma yaklaşımlarının gerekliliği olarak renksel (resimsel) tamamlama ilkelerinin gelișiminin araștırılması ve bu doğrultuda bazı örnek uygulamaların yapılması amaçlanmıştır. Böylece Türkiye'de genellikle göz ardı edilen konunun irdelenerek, örnek uygulamalarla da desteklenerek koruma çalıșmalarına katkıda bulunulması hedeflenmektedir.

Anahtar Sözcükler: Koruma, onarım, tamamlama, renksel tamamlama, resimsel tamamlama, renk karıșımı.

Akademik disipin(ler)/alan(lar): Kültür varlıklarını koruma, güzel sanatlar, sanat tarihi.

\begin{abstract}
The paintings which have a significant place in our cultural heritage can be seen on panels, canvases, murals and various other carrier materials situated in different locations, from archaeological sites to museums and from private collections to architectural structures. Various methods are practiced for the conservation of the paintings depending on their material features and the quality of their conservation. One of the most controversial issues related to the conservation practices is interventions with reintegration purposes, which are carried out to enhance the artistic value and iconographic legibility of the paintings. However, these are not a vital for painting conservation. Such practices, which can rather be seen as cosmetic treatments, emerge as an aesthetic necessity, focusing on the problems associated with the artwork's presentation for the beholder. Since the late 19th century, that requirement has brought about the works in which various techniques, methods and materials have been discussed and distinctive approaches have been developed.
\end{abstract}

By including the development of color theory, the study and the development of color theory aim to investigate the development of the principles of color (pictorial) reintegration as a necessity of conservation approaches and make some sample practices in that direction. As a result, our study aims to contribute to conservation efforts by examining the issue that is often ignored in Turkey and supporting it with sample applications.

Keywords: Conservation, restoration, reintegration, color integration, pictorial reintegration, color mixing.

Academical disciplines/fields: Conservation of cultural properties, fine arts, art history.

- $\quad$ Sorumlu Yazar: Ezgin Yetiş, Sanat Eserleri Konservasyonu ve Restorasyon Bölümü, Güzel Sanatlar ve Tasarım Fakültesi, Kastamonu Üniversitesi.

- $\quad$ Adres: Kastamonu Üniversitesi, Güzel Sanatlar ve Tasarım Fakültesi Dekanlığı, Kuzeykent Yerleșkesi, Kuzeykent Mah. Orgeneral Atilla Pașa Cad. Merkez, Kastamonu.

- e-posta: ezginyetis@hotmail.com

- ORCID: 0000-0003-3375-7432

- Cevrimiçi yayın tarihi: 14.12.2021

- doi: $10.17484 /$ yedi.771578 


\section{Giriş}

İnsanlık tarihinin en eski sanat üretimlerinin başında gelen resimler geçmişten günümüze kullanılan malzeme ve tekniklerle çeşitlilik arz etmektedir. Özellikle üzerine uygulandığı taşıyıcı malzemenin niteliği (ahşap, sıva, bez, taş vb.), tekniğin belirlenmesinde ve koruma çalışmalarında izlenecek yolun seçiminde önemli rol oynamaktadır. Bozulmuş, hasara uğramış resimlerin artistik değeri ile ikonografik okunurluğunu arttırmak için yapılan tamamlamalar teknik olarak çeșitlilik gösterse de estetik sunum olarak tek bir çerçevede değerlendirilir.

Resim konservasyonunda tamamlamaların pratikteki gelişimine yönelik bilimsel içerikli denemeler İtalya'da başlamış ve özellikle Cesare Brandi tarafından 1940'larda Gestalt Kuramının' ${ }^{1}$ görsel algılamadaki bütün ile parça ilișkisi bağlantılı olarak geliștirilen renk tamamlama tekniği ve kuramsal boyutu günümüz yaklașımlarına öncülük etmiștir (Brandi, 1977, s. 71-76). Bu doğrultuda tamamlama/bütünleme veya rötuș olarak adlandırılan uygulama işlemleri optik renk karışımı ilkeleri ile yapılmaktadır. Bu sebeple resimlerde kullanılan tamamlama tekniklerinde önemli yer tutan renk teorisine kısaca değinmek gerekir.

İlk olarak Erken Yunan Arap psikolog ve fizyologları tarafından tanımlanan rengin 1666 yılında Newton'un ıșıktaki renklerin keșfi ile serüveni bașlamıștır. Renk kuramının gelișimi Edme Mariotte (1620-1684), J. C. Le Blon (1667-1741), Moses Harris (1731-1785), Tobias Mayer (1723-1762), J. Heinrich Lambert (17281777), Philip Otto Runge (1777-1810) ve Johann Wolfgang von Goethe (1749-1832) ile önemli bir noktaya gelmiştir (Briggs, 2015; Seylan, 2019, s. 112-123; Goethe, 2020). Hermann von Helmholtz ve James Clerk Maxwell ana ışık renkleri olan kırmızı, yeşil ve maviyi (RGB) keşfetmişlerdir. Michel-Eugene Chevreul (1786-1889) eşzamanlı kontrastlık kanununu ortaya koyarak izlenimcileri az da olsa etkilemiştir. Wilhelm Oswald ve Albert Munsell standart olabilecek renk sistemleri geliștirmişlerdir (Öztuna, 2008, s. 121-124; Ocvirk, Stinson, Wigg, Bone ve Cayton, 2015, s. 200-216; Seylan, 2019, s. 115-116; Per, 2009, s. 21). Takiben Johanness Itten, Faber Birren ve Joseph Albers gibi sanatçı ve bilim insanlarının çalışmaları ile üçlü renk sisteminin tarihsel sistemi netleşmiştir.

Işıktaki renkler beyaz ışık olarak kabul edilen güneş ışığının içerisindeki elektromanyetik enerji olarak da bilinen farklı uzunluktaki dalga boylarından oluşur. Işık renklerinden farklı olarak boya renklerinde ise pigmentasyon ya da renk niteliği olarak bilinen fiziki özellikler mevcuttur. Işık kaynağının varlığında; bir objeye yansıyan ıșık kaynağı içerisindeki bazı renkler emilir, bazıları ise yansır. Yansıyan renk/renkler bize objenin rengini verir (Ocvirk vd., 2015, s. 186, 191). Buna göre teoride siyah tüm renkleri emer ve yansıma olmaz; beyaz ise tüm renkleri yansıtır. Gerçekte siyahta bir miktar yansıma, beyaz ise bir miktar emilme oluşturmaktadır.

Renklerin fiziksel özellikleri renk özü, değer ve yoğunluk olmak üzere üç grupta sınıflandırılmıștır. Renk özü ya da hue olarak adlandırılan özellik rengin çemberdeki yerini belirtir ve o rengin en parlak halidir. Sarı, kırmızı, mavi, yeşil ve mor gibi renk özleri birbirleri ile karışarak limitsiz sayıda renge ulaşılabilir. Değer kavramı rengin göreceli açıklık ve koyuluğunu (ışık-gölge) ifade eder. Her rengin gri ton çubuğunda bir kromatik değer karşılığı vardır. Örneğin, çemberdeki (hue) sarı renk mordan daha fazla ışık yansıtır ve bu sebeple daha parlak görünür (Öztuna, 2008, s. 136; Ocvirk vd., 2015, s. 190; Seylan, 2019, s. 120). Ayrıca bir rengin beyaza yakın ışık değerlerindeki ton farklarını tanımlamak için tint kavramı kullanılır (Genç ve Sipahioğlu, 1990, s. 122). Rengin fiziksel özellikleri olarak renk çemberindeki sarı, kımızı ve mavi birincil renklerini (ana renkler); yeşil, turuncu ve mor ikincil renklerini (ara renkler) belirtmek gerekir.

Sanatçıların armoni kuralları çerçevesinde kullandıkları çeşitli renk kombinasyonları bulunmaktadır. Bu kombinasyonları 12'li renk çemberinde Ocvirk vd. (2015, s. 195-203) ve Öztuna (2008, s. 129-141); tamamlayıcılık, ayrık-tamamlayıcılık, üçlüler, dörtlüler, benzerlik (komşuluk), monokromatik renkler, sıcaklık ve soğukluk ile eş zamanlı kontrastlık olarak belirtmişlerdir. Bununla birlikte siyah, beyaz ve griler nötr olarak düşünülmektedir. Siyahtan beyaza giden bir gri valörde yansıyan ıșığın kalitesinden ziyade miktarından söz edilebilir. Beyaz renklerin varlığı, siyah ise renklerin yokluğu olarak da bilinmektedir.

Renklerin bulunduğu yüzey karakteristiğine göre etkisini belirten lustre ve rengin bulunduğu yüzeyin parlaklığı veya aydınlık olma durumunu belirten luminosite renklerin görsel algılamasını değiştirmektedir. Bunlar renkten ziyade bulunduğu yüzeyin özellikleridir. Yüzeyin pürüzsüz ve ışık miktarından kaynaklı daha aydınlık olması rengin görünümünde görecelilik oluşturacaktır (Genç ve Sipahioğlu, 1990, s. 118-123;

\footnotetext{
${ }^{1}$ Gestalt’ın Almanca karșılı̆̆ı şekil ya da form demektir. Bütünün parçalardan meydana geldiği ve düzenlerin ayrılmaz bir bütün olarak organize edilmesine göre formüle edildiği söylenmektedir. Gruplama şekil-zemin ilişkisi, yakınlık, ortak kader, benzerlik, devamlılık ve kapalılık gibi ilkelere dayanır. Şekil-zemin ilișkisinde zemin veya şeklin bir bütünü olușturan șekil ve zeminden farklı olduğu ifade edilmektedir (Koffka, 1935; Todorovic, 2008).
} 
Seylan, 2019, s. 172-173). Ayrıca Genç ve Sipahioğlu (1990, s. 118-123), renklerin yeğinliğinden (doygunluk) söz etmiştir. Buna göre genellikle açık değerler üzerine uygulanan renkler yüksek bir parlaklık ve yeğinlik ortaya koymaktadır.

Eşzamanlı kontrastlığa bağlı olarak çevreleyen renk, çevrelenen rengi kendinden daha uzun dalga boyu ile algılamaya zorlamaktadır (Seylan, 2019, s. 173-174). Aslında bu durum gri bir bandın siyah zemin üzerinde açık, beyaz üzerinde oldukça koyu görünmesi ile de açıklanabilir.

Konu ile bağlantılı diğer bir özellik ön-arka ilişkisini oluşturan derinlik veya uzam etkisidir. Ocvirk vd. (2015, s. 225-227), sonsuz ve derin uzamı oluşturan perspektif², üst üste bindirme gibi faktörler kullanılmaksızın iki boyutlu düzlemde sadece renklerin etkisi ile olușturulabilen uzamsal etkiyi sı̆̆ uzam olarak adlandırmıștır. Renklerin sıcaklık-soğukluk özellikleri sığ uzamdaki şekil ve zemin ilișkisinde önarka iliş̧kisi olușturmaktadır. Soğuk renkler (mavi, yeșil, mor) sıcakların (kırmızı, sarı, turuncu) yanında daha arkadaymış gibi görünecektir.

Bunun yanında renklerin özellikleri ile ilgili olarak yoğunluk (parlaklık veya saturasyon) değişimleri keskinliklerin değişimine neden olacak ve keskinliğin azalması şekli arkaya doğru itecektir. Rengin yoğunluğunu azaltmanın iki yolu vardır: Biri renk çemberinde tamamlayıcısı ile karıştırıp nötr olan grimsi kahverengiye doğru götürmektir. Diğeri de siyah, beyaz veya gri ekleyerek ton değerini değiștirmektir.

\section{Renk Karıştırma Metotları}

Renk karışımlarını Çağlarca (2018, s. 9-12) toplamsal karışım, çıkarmalı karışım ve bindirme yöntemi olarak üç yolla açıklamıştır. Ancak Briggs (2012), her çeşit renk karışımında toplamsal ve çıkarmalı etkilerin olabileceğinden söz ederek; fiziksel karışım, üst üste bindirme glazing ve optik karışım olarak üç farklı sinıflandırma yapmıştır.

Işsktaki renkler 'toplamsal/additive' olarak kabul edilmektedir. Bunlar görüntüleme sistemlerinde kullanılan, RGB (Red/kırmızı, Green/yeşil ve Blue/mavi) olarak bilinen ve başka renklerden elde edilemeyen ana ışık renkleridir. İkili birleşimlerde: kırmızı ile yeșil sarıyı, yeșil ile mavi (morumsu mavi) Cyanı, kırmızı ile mavi (morumsu) ise magentayı oluşturur. Üst üste bindirildiğinde ise beyaz ışık meydana gelir (Ocvirk vd., 2015, s. 185; Seylan, 2019, s. 117). Televizyon, bilgisayar ve dijital fotoğraf makinesi gibi görüntüleme sistemlerinde üç ışık renginden oluşan piksel grupları kullanılır.

Çıkarmalı renkler boya renkleridir ve yukarıda bahsedildiği gibi ana ışık renklerinin ikili karışımı ile oluşan Cyan, Magenta ve Sarı olarak toplamsal renklerin ikili karıșımından meydana gelirler. Bu sebeple çıkarmalı / subtractive olarak anılmışlardır (Çağlarca, 2018, s. 9; Seylan, 2019, s. 119). Ancak bu pigmentler sanatçının kullandığı ana renk pigmentler olan kırmızı, sarı ve maviden farklıdır. Cyan, magenta ve sarının ikili karışımlarından tüm sanatçı paleti elde edilebilir. Çıkarmalı üç ana rengin karışımı ise siyaha yakın ya da kahverengimsi gri nötr bir renk ortaya çıkarmaktadır (Öztuna, 2008, s. 123-124).

Briggs (2012)'in açıkladığı fiziksel karışımda çıkarmalı renkler ve/veya sanatçının paletindeki renkler kastedilmektedir. Bu tür karışımda renkler göz retinasında karışarak değil de karışımdaki renklerin ıșıkları karıştırılarak sonuca ulaşlır. Yani bileşimin ilgili tüm renkleri karışarak etkileşime girerler. Ancak karışımdaki boyaların eşit şeffaflığa sahip olması gerekir. Aksi durumda bazı renkler karışımın arasından fazla saçılacak ve bu da göz retinasında optik olarak karışmalarına sebep olacaktır. Bu ihtimale dayanarak fiziksel karışım genellikle ortalama-toplamsal /averaging-additive olarak adlandırılan etkiyi de içermektedir. Özellikle örtücü $\left(\mathrm{opak}^{3}\right)$ boyaların karışımında ortalama-toplamsal etkilerin daha fazla olacağı düşünülmektedir. Toplamsal karışımda üç renk arasındaki mesafe arttırıldığında ${ }^{4}$ karışımın toplamının daha az parlak olacağını ve gri görüneceğini söylemektedir. Kısaca karışımın beyazı ve ekranının siyahı birleşerek griyi oluşturmaktadır. Toplamsal karışan RGB beyaz yerine, ortalama-toplamsal olarak adlandırılan gri görünecektir.

Glazing olarak adlandırılan üst üste bindirme yönteminde gelen ışık tüm renk katmanlarından geçerek çıkarmalı karışım ile sonuçlanır. Ancak burada önemli olan üst üste uygulanan renk katmanlarının yeterince şeffaf olması ve bu şeffaflı̆̆ın birbirlerine eşit olmasıdır. Eğer son katman tam olarak şeffaf olmazsa ışık

\footnotetext{
${ }^{2}$ Atmosferik perspektif ve çizgisel (lineer) perspektiften bahsedilmektedir.

${ }^{3}$ Opak sıfatı donuk ve mat renk anlamlarına gelmektedir (Opak, t.y.). Daha detaylı bir açıklama ile ne șeffaf ne de yarı șeffaftır (Opacity (optics) maddesi, t.y.).

4 Briggs (2012), burada renk piksellerinin birbirine yakınlığı ve uzaklığından yani renk noktalarının sıklık ve seyrekliğinden bahsetmektedir.
} 
buradan daha fazla saçllacak ve böylece boya karışımında az miktarda ortalama-toplamsal bir etki olacaktır (Briggs, 2012).

Glazing suluboya tekniğinde çok önemli bir efekttir. İçeriğindeki bağlayıcı maddeden kaynaklı suluboyalar șeffaf veya berrak luminous olarak anılırlar. Bu berraklık özelliği ile renkler üst üste uygulanıp çıkarmalı bir karıșım elde edildiğinde teknik gerçekleștirilmiș olur (Curtis, Anderson, Seims, Fleischer ve Salesin, 1997, s. 421-430). Suluboyada renkler şeffaf olmakla birlikte az sulu kullanıldığında ya da siyah gibi koyu değer renkler kullanıldığında bir miktar örtücü (opak) olabilirler. Kısacası yeterince sulandırılmak sureti ile uygulanan ilk renk kuruduktan sonra diğer renklerde sırayla ve kuruması beklendikten sonra üst üste uygulanır. Renklerin eşit şeffaflığa sahip olması durumunda çıkarmalı bir karışım oluşur. Ancak bu eşitlik pratikte tam olarak mümkün olmadığı için karışım bir miktar ortalama-toplamsal olacaktır.

Optik renk karışımında renkler karıştırılmadan birbirinden bağımsız olarak nokta, leke veya benekler halinde uygulanır. Renklerin karışımı göz retinasında gerçekleşir ve tek bir renk olarak algılanır (Şekil 1). Bu durum öncelikle ortalama-toplamsal renk algısı ile sonuçlansa da şeffaflık ve üst üste binen glazing renklerden dolayı çıkarmalı karışım da içermektedir. Örneğin, mavi ve sarı noktaların karıșımı yeșilden ziyade ortalama-toplamsal karışım olan nötr griyi verecektir. Ancak çıkarmalı etki, gri ile birlikte yeşilin de algılanmasını sağlayacaktır (Briggs, 2012). Itten (1970, s. 65), optik renk karışımını gözde titreşimli ve daha fazla seyreltik algılandığını söylemektedir. Dört renk baskı teknolojisinde kullanılan Cyan, Magenta, Sarı ve Siyah, beyaz zemin üzerinde çok küçük noktalar halinde karışmakta ve optik olarak algılanmaktadır. Baskının kalitesi noktaların küçüklügü ve yoğun kullanımına bağlıdır. Aksi durumda karışımda ortalamatoplamsal etki olacak, bu da seyreltik ve titreşimli algılamaya sebep olacaktır.

Ogden Rood tarafından 1879 yılında savunulan pointilist resim tekniği renk noktalarının birleșerek optik olarak karıșması, gözde yumuşak ve titreşimli bir etki bırakması ile bilinmektedir. Bu tekniğin en yaygın kullanıcısı neo-empresyonist Georges Seurat olmuştur. Seurat ve Rood'un renk özlerini kullanarak yarattıkları teknik, sanatçllara yüksek yoğunlukta renkler kullanarak düşük kroma görünüm elde etmelerini sağlamıştır (Itten, 1970, s. 65; Briggs, 2012).

Resim restorasyonunda, bilhassa renksel tamamlamalarda renk bilgisi ve renk karıştırma teknikleri önemli yer tutmaktadir.
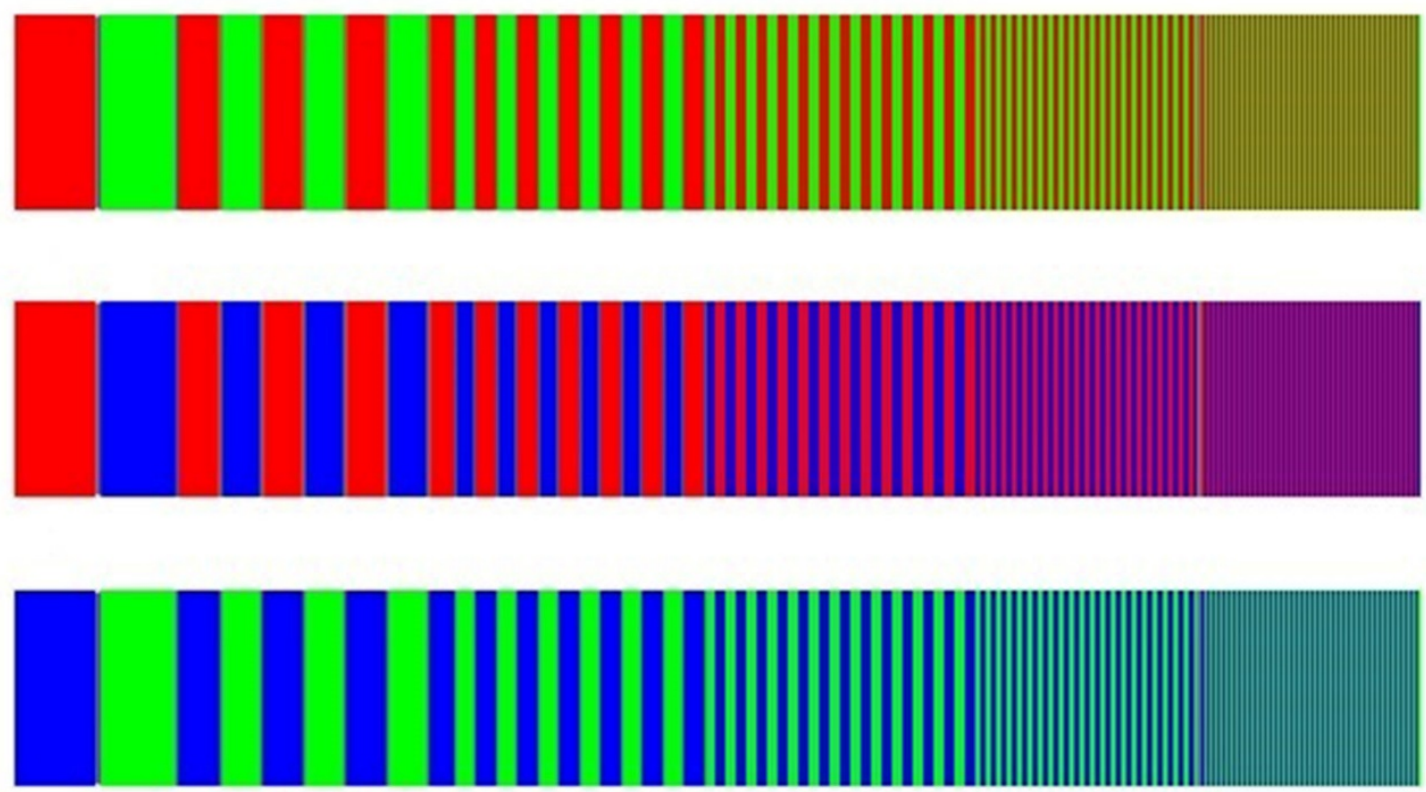

Şekil 1. Optik renk karışımını gösteren şekil (Briggs, 2012). 


\section{Resimlerde Tamamlama İlkeleri}

Resimlerin yüzey temizliği, sağlamlaştırılması, sabitlenmesi ve kayıp alanların dolgulanması doğrudan müdahale gerektiren etkin koruma işlemleridir. ${ }^{5}$ Resim yüzeylerinin zarar görmesi tarihi, estetik ve manevi anlamda değişime yol açarak estetik değer kaybına neden olmaktadır. Kayıp kısımlar sanat eserinin algılanmasını güçleştirmekte ve okunurluğunun önüne geçmektedir. Resimlerin artistik değerini ve ikonografik okunurluğunu arttırmak için kayıp alanların tamamlanmasına dönük çeşitli yöntemler geliştirilmiştir.

İtalyan görsel rötuşu ${ }^{6}$ adıyla bilinen renksel tamamlama tekniklerinin gelişimiyle ilgili önemli adımlar atan Cesare Brandi ve Umberto Baldini, modern restorasyonun öncüleri olarak ilk akla gelen isimlerdir (Muir, 2010, s.19). İtalya'da 20. yüzyılın başlarında gelişmeye başlayan koruma yaklaşımlarına dek amatör restorasyon olarak adlandırılan ressam-restoratörler ile genellikle taklitçi tamamlamalar yapılmaktaydı (Hoeniger, 1999, s. 149). Özellikle 19. yüzyılın sonlarında figüratif tamamlamalar ile önceki dönemlerin ruhunu yaşatmak amaçlı simgesel (emblematic) restorasyonlar yapılmıştır. Hatta John Ruskin merkezli romantik görüş bu tür restorasyonlara karşı çıkmış ve bunlar 1930’lu yıllardan sonra dönem dönem sökülerek temizlenmiştir (Olsson, 2003, s. 4-5).

1930 yılında Roma'da yapılan konferansta ${ }^{7}$ rötuş konusuna özellikle değinilmese de koruma alanındaki kritik problemlere vurgu yapılmıştır (Muir, 2010, s. 19). 1934 yılında Floransa restorasyon laboratuvarının başına Ugo Procacci'nin, 1939 yılında Roma'daki Merkez Restorasyon Enstitüsü'nün başına (Istıtuto Centrale Del Restauro) Cesare Brandi'nin geçmesi ile yaklaşımlar özgün eserlerin korunmasına yönelmeye başlamıștır (Olsson, 2003, s. 6).

1961 yılında New York'ta resim kayıplarının telafi edilmesi ile ilgili felsefi ve pratik sorunlara da değinilen kongrede $^{8}$ Cesare Brandi'nin fikirleri etkili olmuştur. Burada kayıp alanlar için taklitçi tamamlama, tamamlama yapılmaması ve ayırt edici tamamlama gibi kavramlarla ifade edilen yaklaşımlar ilk defa detaylı olarak tartışılmıștır. Özellikle 2002 yılında Yale Üniversitesi'nde yapılan restorasyon tarihi ve erken İtalyan resimlerinin tedavileri konulu kongrede resim kayıplarının telafisi geniş anlamda irdelenmiştir (Muir, 2010, s. 19). Böylece 20. yüzyılın ortalarında değișen restorasyon anlayıșları ile bazı dini sembol niteliğinde olan panel ve tuval resimlerinin de önceki dönemlerde yapılan restorasyonları sorgulanmaya bașlamıştır (Hoeniger, 1999). Hatta yeniden yapılan ya da üstüne yapılan resimler geri alınarak özgün tabakalara ulaşılmaya çalıșılmıştır.

Resimlerdeki kayıplara ilişkin müdahaleler için tartışma konusunu oluşturan üç farklı yaklaşım aşağıda kısaca tanımlanmıştır:

\subsection{Taklitçi Tamamlama}

Mimetik ve ilüzyonist tamamlama gibi farklı isimlerle de anılan yaklaşım; eserin estetik değerini önceleyen bir tutumla resmin kayıp parçasının özgün görünümüne mümkün olduğunca benzetilmesi ișlemidir. Bunlar çıplak gözle orijinalinden ayırt edilemez (Şekil 2). Bu alanda çalışan restoratörler genellikle orijinali taklit etmek konusunda uzman sanatçlar olmuştur (Brandi, 2005, s. 142). Geleneksel bir yaklaşım olan taklitçi tamamlamanın özellikle 1930 ve 1940'lara kadar pek fazla alternatifi yoktur (Muir, 2010, s. 20). 19. yüzyılda restoratörlerin bu tekniğe mahkûmiyeti, bazı kuramcılar sayesinde, 20. yüzyıldan önce bazı katı fikirlerin doğmasına sebep olmuştur. 19. yüzyılın son çeyreğinde Geatano Bianchi'nin Floransa Santa Croce Kilisesi'nin Bardi Şapeli'nde yaptığı oldukça yanıltıcı ve eski dönemlerin simgesel yeniden uygulamalarından oluşan restorasyonu eleștirilmiş; ardından John Ruskin ve Giovanni Battista Cavalcaselle minimal müdahalenin savunucusu olmuş (Olsson, 2003, s. 4-5) ve restorasyon çalışmalarında uzman tutum anlayıșı getirilmiştir.

\footnotetext{
5 Renksel olarak tamamlama terimleri farklı şekilde kullanılmaktadır. Bunlardan bazıları yeniden integrasyon (reintegration), integrasyon (integration), rötuş (retouching), boyama (inpainting), üst boyama (overpainting) gibi terimlerle ifade edilir. Bu terimler genellikle ülkelere göre farklılık göstermektedir (Bailao ve Calvo, 2015, s. 17-22). Reintegrasyon terimi Türkçeye tamamlama olarak çevrilmiştir; Weyer vd. (2015, s. 329) ve Ahunbay (2009, s. 96-97) ise bu terimi bütünleme olarak kullanmıştır.

6 Üst boyamada (overpainting); orijinal resim, orijinal sanatçınınkinden farklı el ile kısmen veya tamamen birkaç kat boya ile kaplanır. Bazı üst boyamalar, kusurlu alanın sınırlarının ötesine taşarak güzelleştirme yorumuyla, geçtiğimiz yüzyıllarda rötuş adı altında boyanmıștır (Nicolaus, 1999, s. 295). Bu sebeple rötuş kelimesi, özellikle yirminci yüzyılın bașına kadar yapılan așırı boyamalar için kullanıldığından bazı teknik belgelemelerde kullanımı kısıtlıdır (Bailao ve Calvo, 2015).

${ }^{7}$ International Conference for the Study of Scientific Methods for the Examination and Preservation of Works of Art.

${ }^{8}$ Twentieth International Congress of the History of Art.
} 


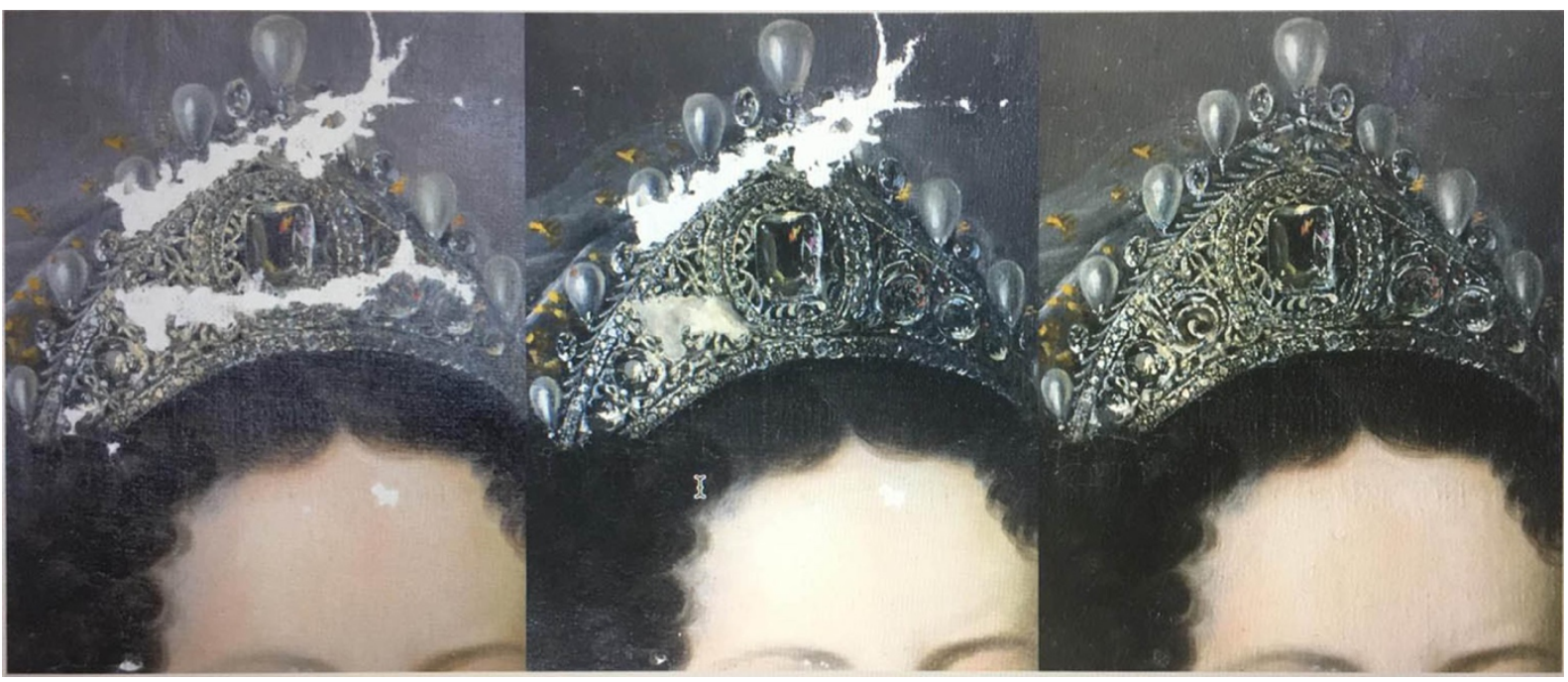

Şekil 2. Yağlı boya tuval resminde mimetik tamamlama uygulaması (Çağlar Eryurt, 2019).

Felsefi bir altyapısı bulunmayan taklitçi tamamlama tekniği tamamen pratikte gelişmiş ve neredeyse 20 . yüzyılın ortalarına kadar kullanılmıştır (Muir, 2010, s. 21). Taklitçi tamamlamalar tarihi değere saygı limiti olmayan bir uygulamaya ve üstüne boyama (overpainting) mantığına dönüştüğü için kabul edilebilir değildir (Mora, Mora ve Philippot, 1984, s. 301; Botticelli, 2003, s. 147). 1950'li yıllarda gelișen anlayıș ile birçok panel resminde önceki rötuşların, hatta yanıltıcı olduğu gerekçesi ile geniş boşluklardaki tratteggio tamamlamalarının bile, geri alındığı görülmektedir (Hoeniger, 1999, s. 151).

Gordon (2000, s. 62-66), geçmişte İtalya'da birçok restoratörün kolay ve kısa sürede uygulandığı için taklitçi rötuşları tercih ettiğini dile getirmektedir. Hatta ayırt edici tamamlama anlayışlarının yaygınlaştı̆̆ı dönemlerde bile restoratörler özel olarak yaptıkları işlerde taklitçi tamamlamalar yapmaya devam etmişlerdir. Özellikle tuval ve panel resimlerinin restorasyonlarında müşteri isteğinin tercih edilen yaklaşımı etkilediği görülmektedir. Bu sebeple Muir (2010, s. 20) resimlerin eksik parçalarının tamamlanmasının gerekliliğini estetik, ticari ve dini değerlere bağlamaktadır. Bailao ve Calvo (2015, s. 1922) da farklı felsefi yaklaşımlar ile değerlendirdikleri renksel tamamlama sürecinde kararın çoğunlukla çalışan uzman gruba ve eserin sosyal içeriğine bağlı olduğunu söylemektedir. Artistik, tarihi, dini, ticari, işlevsel değerler teknik ve yaklaşımın yönünü değiştirmektedir.

\subsection{Tamamlama Yapılmaması}

Resim kayıplarında özel durumlarda tercih edilen bir yöntemdir. Eğer restoratörün yaratıcılığını gerektirecek geniş ebatta kayıplar varsa ya da kayıp kısım tarihi ve kültürel bir değer taşıyorsa yanıltıcı olmasından dolayı tamamlama tercih edilmez. Bazı durumlarda özgün ve yarı tahrip olmuş bir eseri o haliyle görmek daha önemlidir (Şekil 3). Özellikle arkeolojik alanlardaki resimlerde tamamlamayı öncelemeyen müdahalesiz yaklaşımlar tercih edilir (Botticelli, 2003, s. 148). 19. yüzyılın sonları ve 20. yüzyılın başlarında erken İtalyan resimlerine gösterilen yoğun takdir restorasyon süreçlerinde belirleyici bir etken olmuştur. Özellikle bu durum 14. ve 15. yüzyıl eserlerinde sahtecilik ve yoğun restorasyonlar ile sonuçlanmıştır (Muir, 2010, s. 21-22). Müdahalesiz yaklaşım politikası ile bu durumun önüne geçilmeye çalışılmıştır. İkinci Dünya Savaşı sonundan itibaren arkeolojik restorasyon adı altında bilhassa yoğun tahribata uğramış duvar resimlerinde bu yaklaşım kendine uygulama alanı bulmuş; çoğu zaman resimler temizlendikten sonra aşınmış yüzeyler ve kayıp alanlarıyla birlikte mevcut şekliyle korunmuştur (Botticelli, 2003, s. 148). 


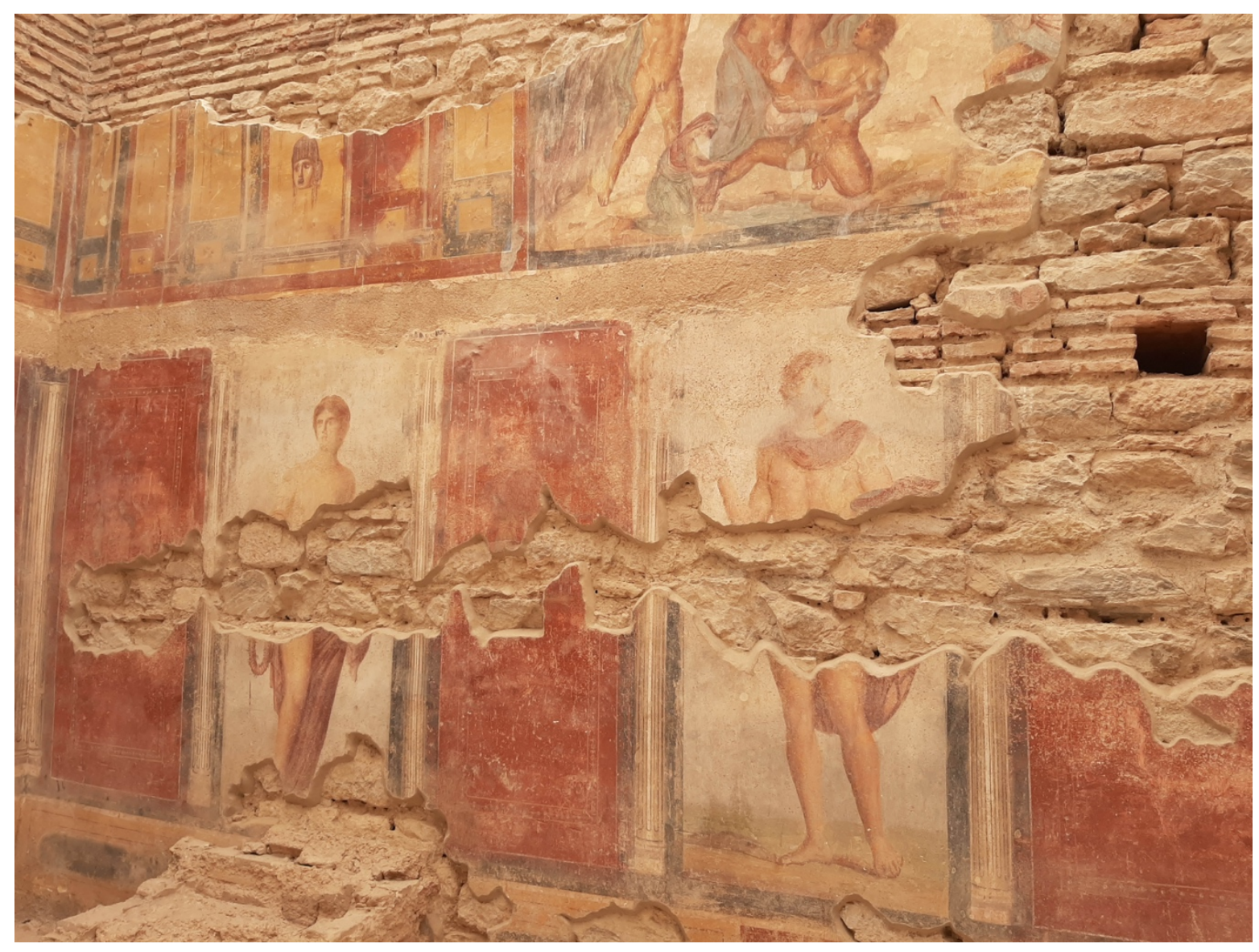

Şekil 3. Tamamlama yapılmadan korunmuş duvar resmi (Efes yamaç evler duvar resimleri, M.S. 100-300a).

\subsection{Ayırt Edici Tamamlama}

Resimlerin kayıp kısımlarını çıplak gözle anlaşılır biçimde tamamlayarak görsel etkisini arttırmak amaçlı kullanılır. Bu sebeple taklitçi tamamlama ve tamamlama yapılmaması arasında bir yaklaşım olduğu söylenebilir. 20. yüzyılın başlarında gelişmeye başlayan modern restorasyon teorisinden önce resimlerin kayıp kısımlarında tarama ve noktalama gibi teknikler ayırt edici olması amacı ile zaten kullanılıyordu. Hatta 20. yüzyılın başlarında -Brandi'den ${ }^{9}$ önce- renksel tamamlamaların orijinal resimden hafifçe açı tonda yapılması gerektiği dile getirilmiştir (Muir, 2010, s. 22-23). Ancak 20. yüzyılın başlarına dek ayırt edici tekniklerin kullanımı ile ilgili kuramsal bir alt yapının olmadığı söylenebilir.

New York'taki kongrede (1961) dile getirilen ilkeler, konunun geliştirilmesinde ilk kuramsal yaklaşımlardan biri olmuştur. Tamamlama öyle bir yapılmalıdır ki, sanat eserinin kayıp parçaları da dahil olmak üzere bir bütün olarak algılanmalı ve eserin okunurluğu sağlanmalıdır (Mora vd., 1984, s. 302-303). Özellikle anıtsal bir yapı içerisindeki resimler yapı ile bir bütünlük oluşturmaktadır. Bu sebeple mimariden bağımsız düșünülemeyen resim kayıplarının tamamlanması resmin mimari mekânda oluşturduğu gerçekliği bütünlemelidir (Mora vd., 1984, s. 1-16, 304).

Brandi'ye göre kayıp alanları tümevarım veya benzetme yoluyla bütünlemeyi amaçlayan herhangi bir müdahale, yaratıcısı olmadığımız için, sanat eserinin soyut düşüncesinin ötesine geçen bir müdahaledir. Sanatçının eksik olan parçayı yarattığı o anı geri getiremeyiz, dolayısıyla bize düșen sanat eserine saygı duymak ve günümüze geldiği şekliyle onun bütünlügünü korumaktır. Bu yaklaşımla kendimizi geriye kalanlarla sınırlandırmalı, analojik bütünleme yapmaksızın sanat eserinin herhangi bir kısmının özgünlüğünden şüphe duyulmasına yol açılmamalıdır. Bazı boşlukları varsayımsal (hipotetik) bütünleme olasılığı, belirli durumlar için sadece kısmi bir çözümdür, marjinaldir; ancak, örneğin eksik bir başın veya buna benzer bir unsurun varsayıma dayalı bütünlenmesinin kabul edilmesi mümkün değildir (Brandi, 1977, s. 73). 
Her resmin hem estetik hem de tarihsel bir rol oynamakta ve birlikte bölünmez bir birlik oluşturmaktadır. Rötuş, bu parçaların hiçbirinin veya birliğin baskın olmayacağı, böylece diğerinin zarar görmeyeceği șekilde yapılmalıdır. Brandi (1977, s. 75) ilkelerini Koffka (1935)'nın Gestalt kuramına göre kurgulamıştır. Gestalt'ın ilk prensibi olarak şekil-zemin etkileşiminde; farklı renk veya ton ile etüt edildiğinde, şekli çevreleyen zeminin şeklin yanında arka planda kaldığını, şeklin ise belirgin sınırları varmış gibi ortaya çıktığını dile getirmektedir. Burada şekil zeminden bağımsız düşünüldüğünde parçaların algısında ayırt ediciliğin olmadığı anlaşılmakta ve her ikisi de bütünü ifade etmemektedir. Şekil ve zemini birbirinden ayıran unsur renk olduğunda, şekil zeminden sanki kontörler ile ayrılıyormuş gibi algılanmaktadır. Parlak görünen eksik kısımları uzamsal bir etki ile öndeymiş etkisi yaratmakta ve arkada hissi verilerek tersine çevrilmek durumundadır (Koffka, 1935, s. 177-305; Brandi, 1977, s. 75).

$\mathrm{Bu}$ durum eşzamanlı kontrastlık konusu içerisinde bahsedilen çevreleyen rengin çevrelediği rengi kendinden daha ileride dalga boyunda algılamaya zorlaması ile açıklanabilir. Seylan (2019, s. 173-174) ve Itten (1970, s. 53-54) kontrastlık tablosunda nötr gri ve kromatik renklerin aralarındaki etkiyi gösteren temel alternatifleri göstermiştir. Burada şekil zemin ilişkisinde olduğu gibi zıtlığın vermiş olduğu titreşim şeklin etrafında kontör algılamasına sebep olmaktadır. Ancak açık-koyu veya sıcak-soğuk keskinliği azaldığında bu titreşimin önüne geçilebilir. Bu prensiplere göre tamamlama yönteminin amacı, resimlerdeki kayıp parçaların baskın etkisini azalmak ve onları resmin görünümüne dahil etmektir.

Şekil ve zemin ilișkisi için yüz-vazo örneğinde siyah ile beyazın zıt vurgusundan kaynaklı olarak eșzamanlı olarak şekil ve zemin algısı mümkün değildir. Ya vazo ya da yüz olarak algılanır (Şekil 4). Duvar resimlerindeki sıva kopmalarının yarattığı boşlukların delik olarak algılanmasına benzer. Boşluk delik olarak oldukça arkada görünür. Sıva ile doldurulduğunda ise beyazın parlaklığından kaynaklı olarak ön plandadır. Burada düzenli köşe dönüşlerinin olduğu (üçgen, kare, yamuk vb.) sıvaların, girintili köşelerden oluşan sıvalardan daha fazla algılandığını da söylemekte fayda vardır (Mittone, 2010, s. 301). Bu sebeple resimlerdeki kayıp kısımların şekli, izleyicideki algılamanın boyutunu değiştirecektir.

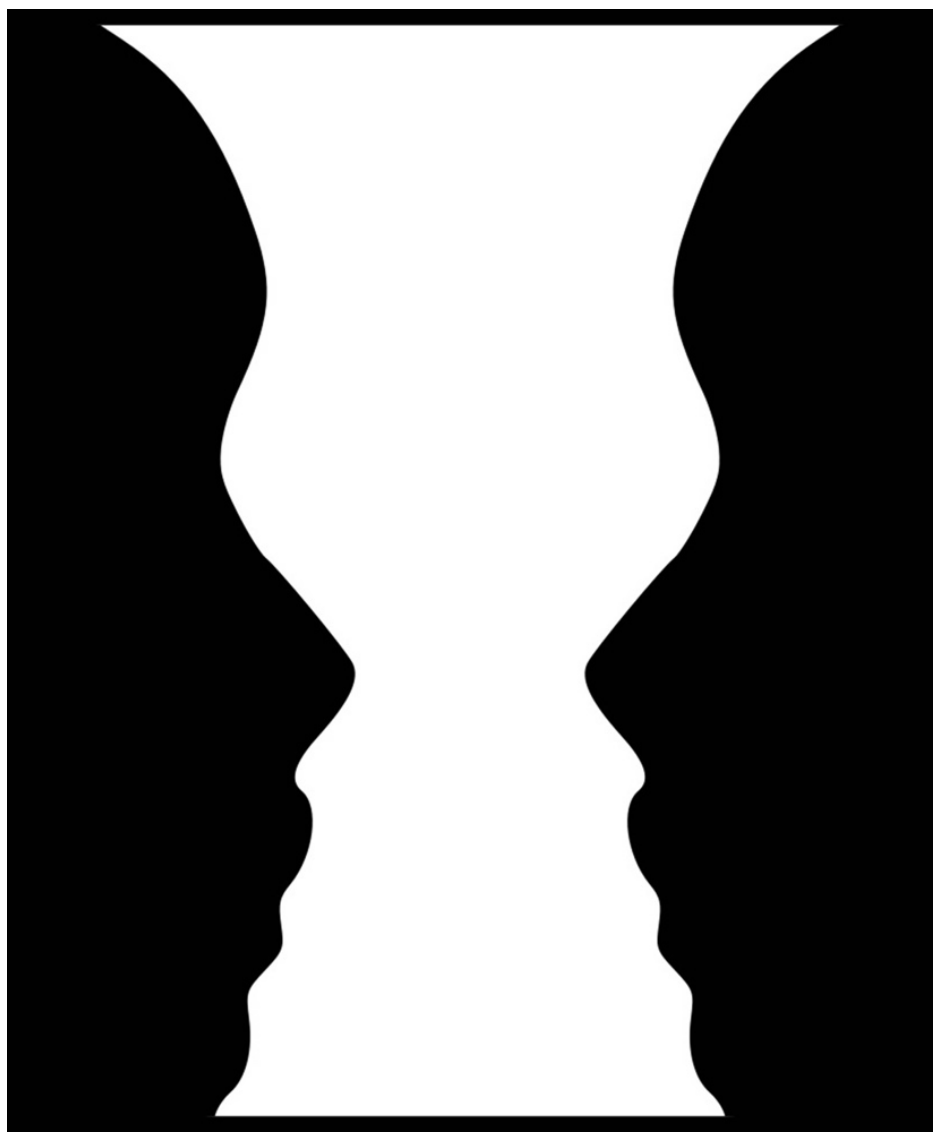

Şekil 4. Şekil-Zemin ilişkisi (Derksen, 2005). 
Resimlerdeki kayıp tamamlamalarının estetik değeri ya da görünümü eserin tarihi ve sanatsal öneminin önüne geçmemelidir. Resim kayıplarındaki rahatsız edici unsurlardan birinin görseli algılama problemi, diğerinin ise görseldeki devamlılığın kesintiye uğraması olarak açıklanmaktadır.

Mora vd. (1984, s. 301-315) duvar resimlerinin kayıp kısımlarının niteliğine göre tamamlama yöntemlerine ilișkin sınıflandırma yapmış̦ır. Patina ve benzeri yüzey kirleri için suluboya ile yapılan glazing tekniği önerilmiştir. Küçük ebattaki noktasal aşınmalar için ton altı tekniğini, varsayım gerektirmeyen yeniden yapılabilir kayıplar için tratteggio ve diğer durumlar için genellikle nötr ton kullanımından bahsetmiştir.

Zaman içerisinde çeşitli değişimler geçirmiş ve kayıplar vermiş olan tarihi eserler, sadece yapıldığı dönemin saflığı ile değil, aynı zamanda zaman içerisindeki süreci ile de tarif edilmelidir (Grenda, 2010, s. 3). Onun özgünlüğ̈ tüm bu özelliklerinin birleşimidir. Özgünlük ile birlikte tamamlamaların geri döndürülebilirliği ve anlașılabilir olması da önem arz etmektedir (Agulli ve Silva, 2015, s. 95-102). Yeterli belge olduğu takdirde tamamlamanın en önemli unsuru şekil veya kromatik devamlılığıdır. Kullanılacak malzemenin özellikleri iyi bilinmelidir. Özellikle tüm tekniklere uygun olarak suluboya kullanımı hem geri dönüşümü kolay hem de şeffaflık özelliğinden dolayı yaygındır. Mora vd. (1984, s. 309) duvar resimleri için suluboyanın; Gordon (2000, s. 62-66) tempera resimler için suluboya, yağlı boyalar için vernik boyaların kullanımından bahsetmiștir. Günümüzde oldukça geniş bir yelpazeye sahip geri dönüșümlü boyalar kullanılmaktadır. Bailao ve Cardeira (2017, s. 248-255) su bazlı bağlayıcılardan oluşan suluboyalar haricinde, solvent bazlı bağlayıcılar ile kuru boyaların kullanım özellikleri ve karşılaştırmalarını ortaya koymuștur. Malzemenin geri döndürülebilir olmasının yanında ıșı̆̆a dayanıklı, nem ve ısı konusunda istikrarl, biyolojik ataklara dirençli, toksik olmayan maddelerden oluşması gerekmektedir.

Renksel tamamlama teknikleri 20. yüzyılın başları ile birlikte koruma bilimi içerisinde kuramsal bir altyapı ve çeşitli yaklaşımlarla gelişmiştir. Bu çerçevede, arkeolojik alanlarda tercih edilen müdahalesiz yaklaşım haricinde, resimlerin kayıp parçalarının tamamlanmasında taklitçi tamamlama ve ayırt edici tamamlama olarak iki türlü yaklaşımdan söz edilebilir. Yüzyıllardır yapılan taklitçi tamamlamalar eserin tarihi ve sanatsal niteliğine karşı yanıltııı bir sonuç oluşturmuştur. Sanatsal ve tarihi açıdan tercih edilmesi oldukça zordur. Çeşitli tekniklerle gelişen ayırt edici tamamlama tarihi ve sanatsal niteliğe saygısı bakımından daha çok benimsenmiş görünmektedir. Ancak uygulanan teknik kayıp parçanın niteliğine göre seçilerek yanıltıcılığın azaltılması gerekir. Bu doğrultuda yaygın olarak bilinen 5 farklı ayırt edici tamamlama tekniği kullanılmıștır. Bunlar tratteggio, kromatik seçim, kromatik soyutlama, nötr tamamlama, ton altı (tonal ayarlama) tamamlama başlıkları altında irdelenmiștir.

\subsubsection{Tratteggio}

Tratteggio ${ }^{10}$ İtalyanca'da tarama anlamına gelen bir kelime olup, eksik kısımların tamamlanmasında birbirinden ayrı tonlar kullanılarak tarama veya firça darbeleri ile yapılan ayırt edici bir tamamlama tekniğidir (Şekil 5). İlk amaçlanan rötuşu özgün resimden ayırt etmektir. İkincisi ise düz çizgiler veya firça vuruşları ile mekanik bir sistem oluşturarak restoratörün eserin sanatsal niteliğine etkisini önlemektir (Mora vd., 1984, s. 309). Böylece bir sistem oluşturularak rötuş müdahalesindeki hatalar en aza indirgenir ve resim okunabilir duruma gelir. Nötr tamamlamadan farkı, yüzeyin tarama çizgileriyle canlandırılmasıdır (Nicolaus, 1999, s. 291).

Doerner (1984), 1922 yllında zaten kullanılan tratteggio tekniğini tarif etmiştir (akt. Muir, 2010, s. 22-23). Teknik, 14. yüzyılın İtalyan ustalarının tempera hazırlı̆̆ ve Divizyonizm ${ }^{11}$ tekniğinin teorik detaylandırılmasından ilham alınarak 1945-1950 yılları arasında Cesare Brandi yönetiminde Roma'daki Merkez Restorasyon Enstitüsü’nde (ICR) geliştirilmiştir (Brandi, 1977, s. 74; Nicolaus, 1999, s. 291; Pascual ve Patino, 2003, s. 119). Ancak teknik 1940'lı yıllara, hatta Cesare Brandi'nin 1963 yılında basılan kitabına kadar kabul edilen bir yaklaşım olamamıștır (Muir, 2010, s. 23). Özellikle 2. Dünya Savașıı'nda yaşanan tahribat sonrasında yaygın olarak renksel tamamlamalarda kullanılmıştır. Brandi'nin yaklaşımı ile ilk defa, Viterbo'daki Santa Maria della Verità kilisesinin Mazzatosta Şapel freskolarında uygulanmıştır (Muir, 2010, s. 23; Ersen, 2011). Tarama tekniğinin kullanıldığı diğer teknik yaklaşımların zaten kullanılan bir teknik olan tratteggiodan türetildiğini söylemekte fayda vardır.

Teknik, temelde Brandi'nin özgünlük ve potansiyel bütünlük kuramlarını temsil eden estetik bütünlügün sağlanması ve aynı zamanda yapılan müdahalenin kolayca anlaşılabilir olması ilkesine dayanmaktadır. Su

${ }_{10}$ Tratteggio tekniği için diğer bir isim olarak rigatino da kullanılmaktadır (Nicolaus, 1999, s. 291; Botticelli, 2003, s. 150; Mittone, 2010, s. 302).

${ }^{11}$ Divizyonizm, Neo-Empresyonizm (Yeni İzlenimcilik) akımı döneminde Noktacılık (Pointilism) tekniğiyle birlikte kullanılan renkleri ayrıștırma tekniğidir. Bu tekniğin ana fikri, renkleri karıștırmadan birbirinden bağımsız bir șekilde yerleştirmektedir. Böylece renkler izleyici için doğal optik yıllarla karıştırarak daha titreşimli ve yoğun bir renk algısı yaratmaktadır (Hodge, 2016, s. 89). 
bazlı boyalarla (acquarello) yapılan tratteggio uygulaması özgün malzeme ve teknik ile bütünlenmiş resmin malzeme ve tekniği arasında anlaşılır bir fark oluşturmaktadır. Böylece kendi çağının damgasını vuran ve yapılan bütünlemeyi gizlemeyen, bir müdahale biçimi oluşturulmuştur (Brandi, 1977, s. 74).

Uygulama eksik kısımlarda fırça ile yaklaşık olarak $1 \mathrm{~cm}$ uzunlukta kısa dikey/diagonal çizgiler atılarak yapılır. İlk tonun çizgileri atıldığında, çizgiler arasında yaklaşık olarak çizgi kalınlığında mesafeler vardır. İkinci ve üçüncü tonlarda çizgi arasındaki boşluklar dolarken bazı çizgiler üst üste gelecektir. Üst üste gelen şeffaf renklerin yaratacağı titreşim rötuşu orijinal resimden ayırt etmeyi sağlayacaktır (Mora vd., 1984, s. 309-310). Benzer titreşimler Yeni İzlenimcilerin kullandığı pointilist teknikte de görülmektedir (Mittone, 2010, s. 302; Nicolaus, 1999, s. 291). Dikey/diagonal çizgilerin kullanılması ve daha uzunca olması diğer tekniklerden ayıran en önemli faktördür. Çizgiler; açıktan koyuya, soğuktan sıcağa, ışıktan karanlığa doğru bir hareket tarzı ile kurgulanır. Kromatik yapılandırma (chromatic reconstruction) olarak da düşünülen teknik özellikle küçük ve orta ebatta boşluklarda kullanılır (Nicolaus, 1999, s. 291). Tratteggio ile hem kayıp kısmın kompozisyonu yeniden yapılabilir hem de kayıp kısmın genel tonlaması devam ettirilebilir (Muir, 2010, s. 23).

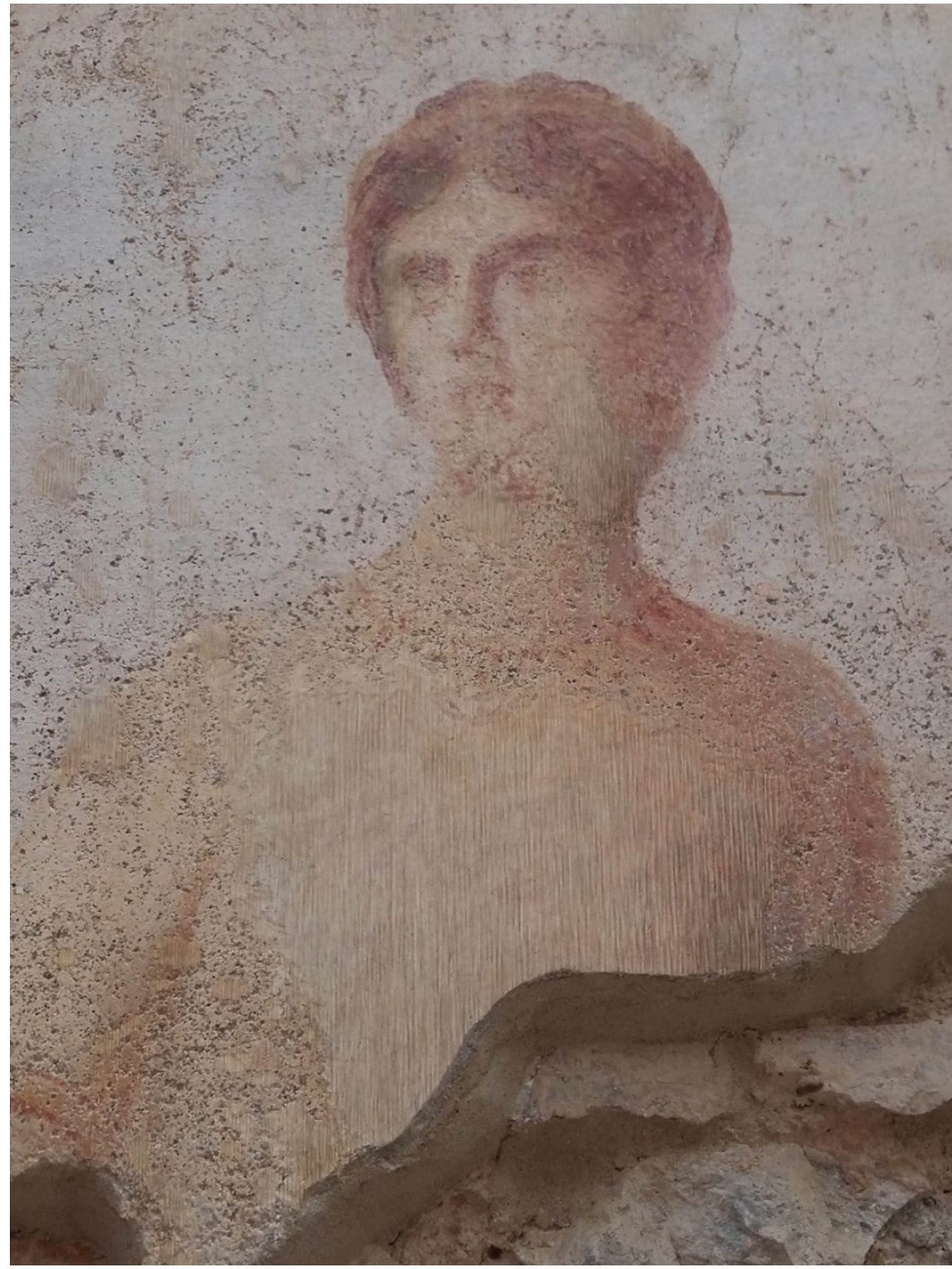

Şekil 5. 2,1 no'lu konut birimi 'tiyatro odasının' SR 6 kuzey duvarı tratteggio uygulaması (Efes yamaç evler duvar resimleri, M.S. 100-300b).

Tratteggionun resimlerdeki tamamen kayıp parçaların yerinde kullanıldığı, aksine asla özgün resmin aşınmış kısımlarında kullanılamayacağı vurgulanmaktadır. Aşınmış kısımlarda glazing tekniği suluboyalar kullanılarak şeffaf renklendirme tekniği tercih edilmiştir (Mora vd., 1984, s. 310-314). Yapılma süreci oldukça zaman aldığı için geniş boşluklarda tercih edilmemiştir. Tratteggio dan yola çıkılarak geliştirilen diğer iki teknik ise kromatik seçim ve kromatik soyutlamadır. 


\subsubsection{Kromatik Seçim}

1970 ve 1980'lerde Floransa'da Brandi'nin tamamlama yaklaşımlarını geliştiren Umberto Baldini Floransa Restorasyon Laboratuvarı'nın başında iken tratteggio tekniğinin tatmin edici olmadığını düşünerek bu teori çerçevesinde kendi teknik ve yaklaşımlarını geliştirmiştir (Baldini, 1997 ve 2001).

Özellikle algı ve optik prensipleri bağlamında kromatik seçim/seçilmiş renk (selezione cromatica) ve kromatik soyutlama/ renk soyutlama (astrazione cromatica) metotlarını ortaya koymuștur. Günümüzde bu iki tekniğin daha yaygın olarak kullanıldığını izlemek mümkündür. Bu iki teknikten birinin tercihinde resmin bütününde meydana gelen kayıpların niteliği ve boyutu belirgin rol oynamaktadır. İlki kayıp alanların (lakuna) sınırlı, resmin bütünlenmesi için desen ve formların yeterli olduğu durumlarda uygulanmaktadır. İkincisi, mevcut resim ile kayıp alanlar arasında şekli bir bağlantı kurulamıyor, desen ve figürler tanımlanamıyorsa tercih edilmektedir. Bu durumda sadece renklerle gerçekleştirilen bir bağlantı söz konusudur. (Boticelli, 2003, s. 148-150).

Küçük ve orta ebatta boşluklarda kullanılan kromatik seçim, tratteggiodaki gibi tarama yöntemi ile yapılır ve tratteggiodan farklı olarak kısa fırça vuruşları tercih edilir. Çizgiler dikey yönde olmak zorunda değildir; aksine resim yüzeyinin model ya da vuruşlarını takip edebilir. En önemli farklılığı renk birleştirme için sadece birincil renklerin tercih edilmesidir (Casazza, 2007, s. 29-64; Nicolaus, 1999, s. 291). Kromatik seçimin tercih edilmesindeki en önemli ilke; özgün resmin eksik parçalarının herhangi bir yaratıcılık veya yorumlama gerektirmeden yeniden yapılabiliyor olmasıdır. Özgün kısımlara bağlı olarak form ve rengin tamamlamasına izin veren küçük düzeltmeler için kullanılmaktadır (Muir, 2010, s. 24; Nicolaus, 1999 , s. 291).

Teknik, bir dizi örtüşen (üs tüste bindirilen) farklı renkten oluşur ve yeniden yapılandırmak istenilen rengin bileşenleri beyaz hariç ana renklerden seçilir. Farklı renk tonlarını vurgulamak için örneğin, kırmızı-sarıkırmızı-siyah ve yeşil kullanılır. Uygulama, bütünlenecek detayın resimsel biçimini takip ederek küçük bir fırça ile küçük taramalar kullanılarak yapılır. Renkler üst üste gelse de kendi aralarında bazen birleşen, bazen de birbirlerinden hafifçe uzaklaşan renk titreşimiyle dalgalı bir görüntü oluşturur. Böylece müdahale alanı yakın mesafeden bütünüyle tanınabilir ve orijinal renkten mükemmel bir şekilde ayrılırken, uzaktan resmin yeniden okunurluğu ve bütünlüğü kazanılmış olur (Boticelli, 2003, s. 150). Üst üste gelen taramalar hem çıkarmalı hem de ortalama-toplamsal bir karıșım oluşturarak pointilizm de olduğu gibi huedeki renklerin yüksek kroması azalır ve hafif gri bir görünüm de oluşturur. Taramadan kaynaklanan titreşimli etki ile birlikte özgün kısımlar arasında ayırt edici bir görünüm ortaya çıkar (Şekil 6).

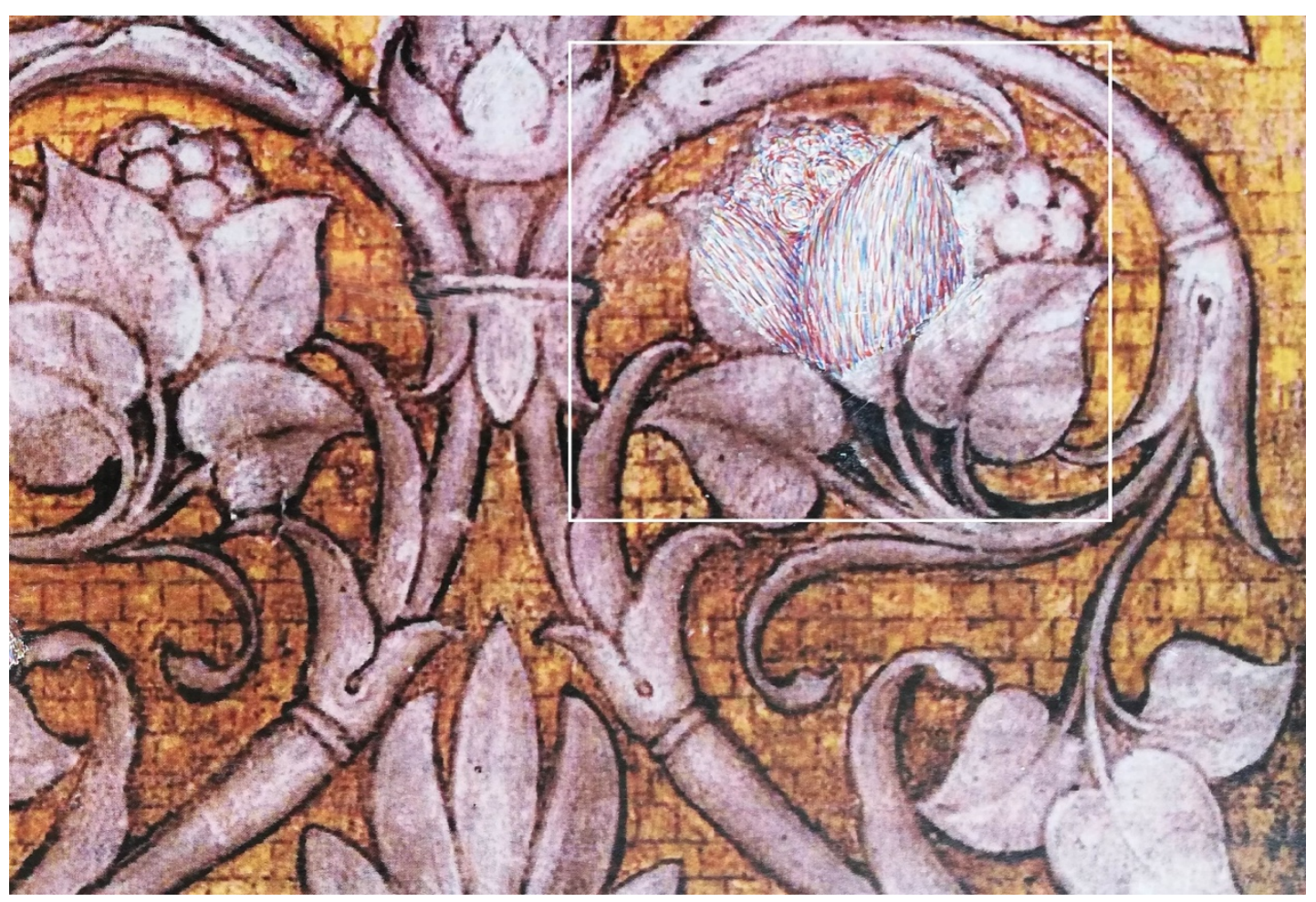

Şekil 6. Kromatik seçim renk tamamlama uygulaması (Yetiş, 2020a). 


\subsubsection{Kromatik Soyutlama}

Geniş boşluklarda kullanılan kromatik soyutlama tekniği, özgün resimdeki eksik kısımların etrafındaki renklerin sonucudur. Çoğunlukla birincil renkler kullanılır ancak özgün kısımlardaki baskın renklere bağlı olarak; genellikle dörtlü sarı/kırmızı/yeșil/siyah, sarı/kırmızı/mavi/siyah, sarı/turuncu/mavi-yeşil/siyah ve sarı/kırmızı/mavi-yeșil/siyah alternatifleri de tercih edilebilir (Casazza, 2007, s. 65-84; Nicolaus, 1999 , s. 291). Birincil renklerin kullanımı ile eksik kısımların etrafındaki baskın renklerin ortalaması sonucu resmin geneliyle uyumlu bir nötr ton yaratılır ve kromatik seçimde olduğu gibi kısa firça vuruşları ile sonuca ulaşılır. Kırmızı, yeşil ve siyah konturlar çapraz olarak zıt yönde uygulanır (Nicolaus, 1999, s. 291). Bu renklerin birbirine girmesi, bazı konturları saf renklerinde görünür hale getirecek ve diğerleri bir glazing etkisi ile kaplanacaktır.

Eğer eksik kısımlar yaratıcılık ya da yorumlama olmaksızın tamamlanamıyorsa kromatik soyutlama tercih edilebilir. Buradaki çizgiler resimdeki şekilleri tamamlamaz ve kullanılan birincil renkler resmin eksik kısmının etrafındaki kromatik özelliklerin tümünden türetilir (Botticelli, 2003, s. 250; Muir, 2010, s. 24). Boşluklar ve özgün resim kısımlar arasındaki nötr bağlantıyı oluşturmayı, sanat eseri içinde tarafsız kalmayı ve yakın bir bağlantı kurmayı amaçlar (Nicolaus, 1999, s. 291). Konsept olarak nötr tamamlama ile oldukça benzerdir ancak tarama ya da noktalamadan kaynaklanan renk titreşimleri ile nötr tamamlama ve glazing ile yapılan diğer tekniklerden farklıdır (Şekil 7).

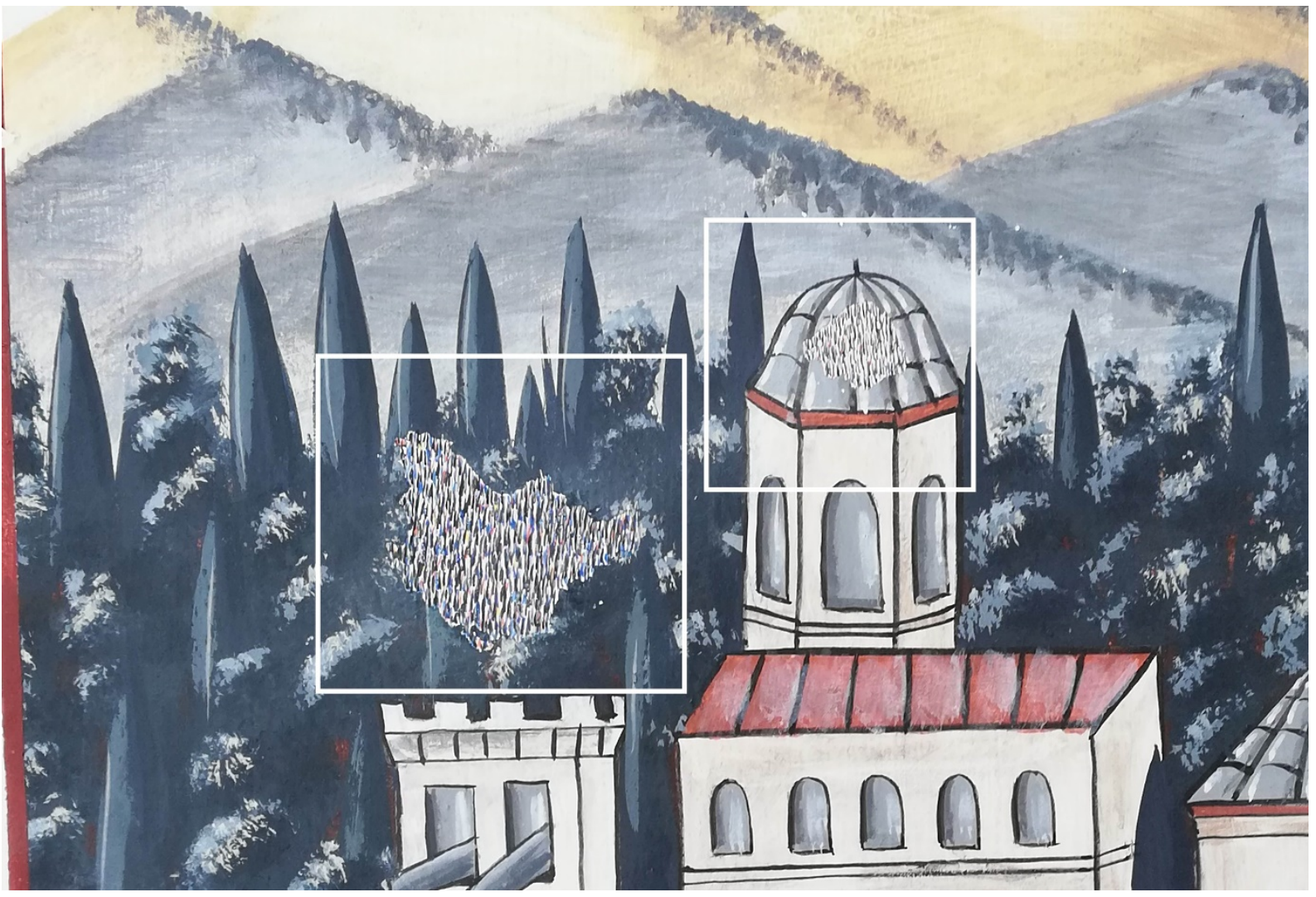

Şekil 7. Kromatik soyutlama renk tamamlama uygulaması (Yetiș, 2020b).

\subsubsection{Nötr Tamamlama}

Resimlerdeki geniş kayıplarda ve figüratif unsurlarda tamamlamanın varsayımsal olacağı durumlarda ${ }^{12}$ tercih edilir (Gordon, 2000, s. 63; Pascual ve Patino, 2003, s. 191). Eksik kısımların oluşturduğu açık ve parlak tonun rahatsız ediciliğini ortadan kaldırmak için renk veya renklerin nötr tonları kullanılarak yapılır. Özellikle arkeolojik alanlardaki resimlerin kayıp kısımları için (Mora vd., 1984, s. 312); yaygın olarak duvar resimlerinde tarihi belge niteliği taşıyan sanat eserlerindeki kromatik devamlılığı sağlamak için tercih edilmiştir (Mittone, 2010, s. 302). Ancak geniş ebatlı ve yeniden yapılması mümkün olmayan kayıplarda da kullanılması uygundur (Şekil 8).

\footnotetext{
${ }^{12}$ Resmin içerisindeki bir yazıt, yazı veya sanatçıya ait bir imza gibi tamamlanması güç olan durumlardan bahsedilmektedir.
} 

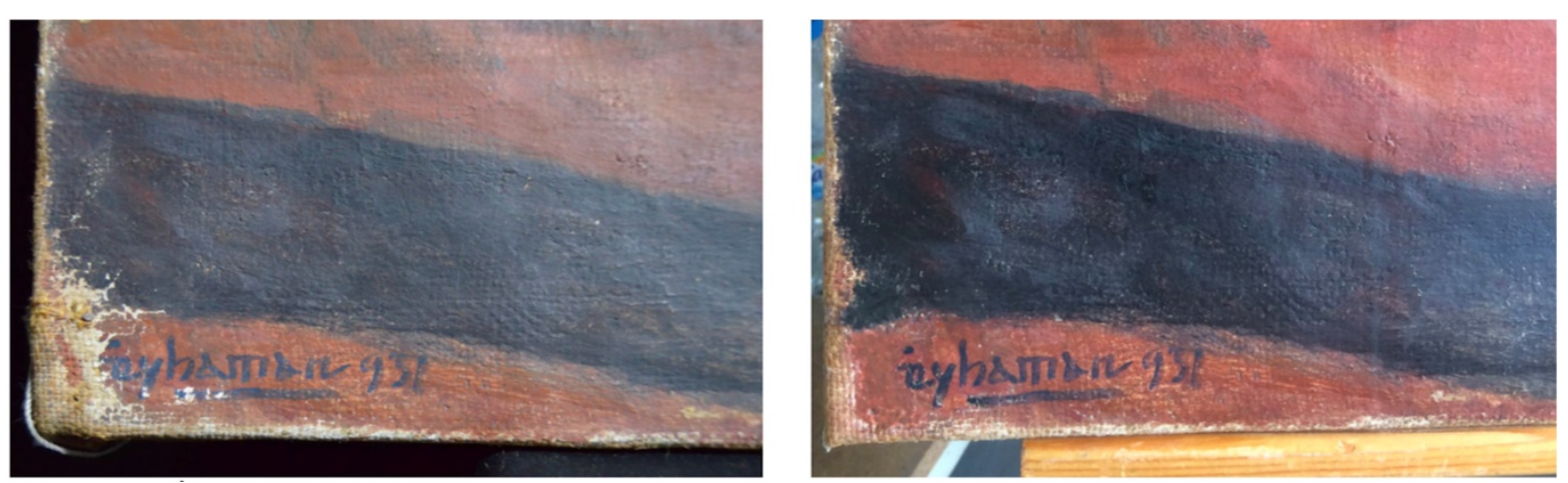

Şekil 8. Nötr tamamlama örneği detay; öncesi (solda) ve sonrası (sağda) (Çağlar Eryurt, 2017, s. 90).

Arkeolojik alanlarda ve tamamlama için doküman eksikliklerinde, özellikle geniş kayıpları bulunan duvar resimlerinde, sıvaların parlak ve rahatsız ediciliğini engellemek amaçl, renklendirme uygulamaları da yapılmaktadır. Bu teknik ile Trompe-l'oeil ve dekoratif resimlerin (tekrar eden süslemeler) tamamlamalarında tratteggio kullanımının zorluklarına karşın, özgün resmin renklerinin hafifçe düşük tinti kullanılarak yeniden yapılması sorunları hızlıca çözmektedir. Bunların yanında eksik kısımların sıvalarının özgün yüzey ile aynı ya da daha alçak seviyede yapılması (Mora vd., 1984, s. 311-315; Mittone, 2010, s. 302303), kayıp kısımların daha arkada görünmelerini sağlayarak ayırt ediciliği arttırmaktadır.

Aslında nötr tamamlamada bahsedilen nötr tonlar ya da renkler değildir. Tamamlamada kullanılan nötr renk boşluğun çevresindeki renkler ile ilişkili olmalıdır. Bu sebeple restoratöre bağlı olarak görecelidir. Belirli bir renk özüne sahip olmayan ve griye kaçan karışımdır. Bu karışım yakınındaki özgün kısımlardan ayrı durmayan, tersine onları birleştiren ve izleyiciye en az rahatsızlı̆̆ veren nötr tonda olmalıdır (Conti, 2007, s. 435). Althöfer'e (1974, s. 78) göre, gri bir ton kullanılırsa, bitişikteki orijinal yeşil tonlar izleyiciye daha kırmızımsı bir renk olarak görünür. Aynı şekilde, yeşil olanların yanındaki mavi tonlar mavinin mor görünmesini sağlar, çünkü kontrast kırmızı üretir.

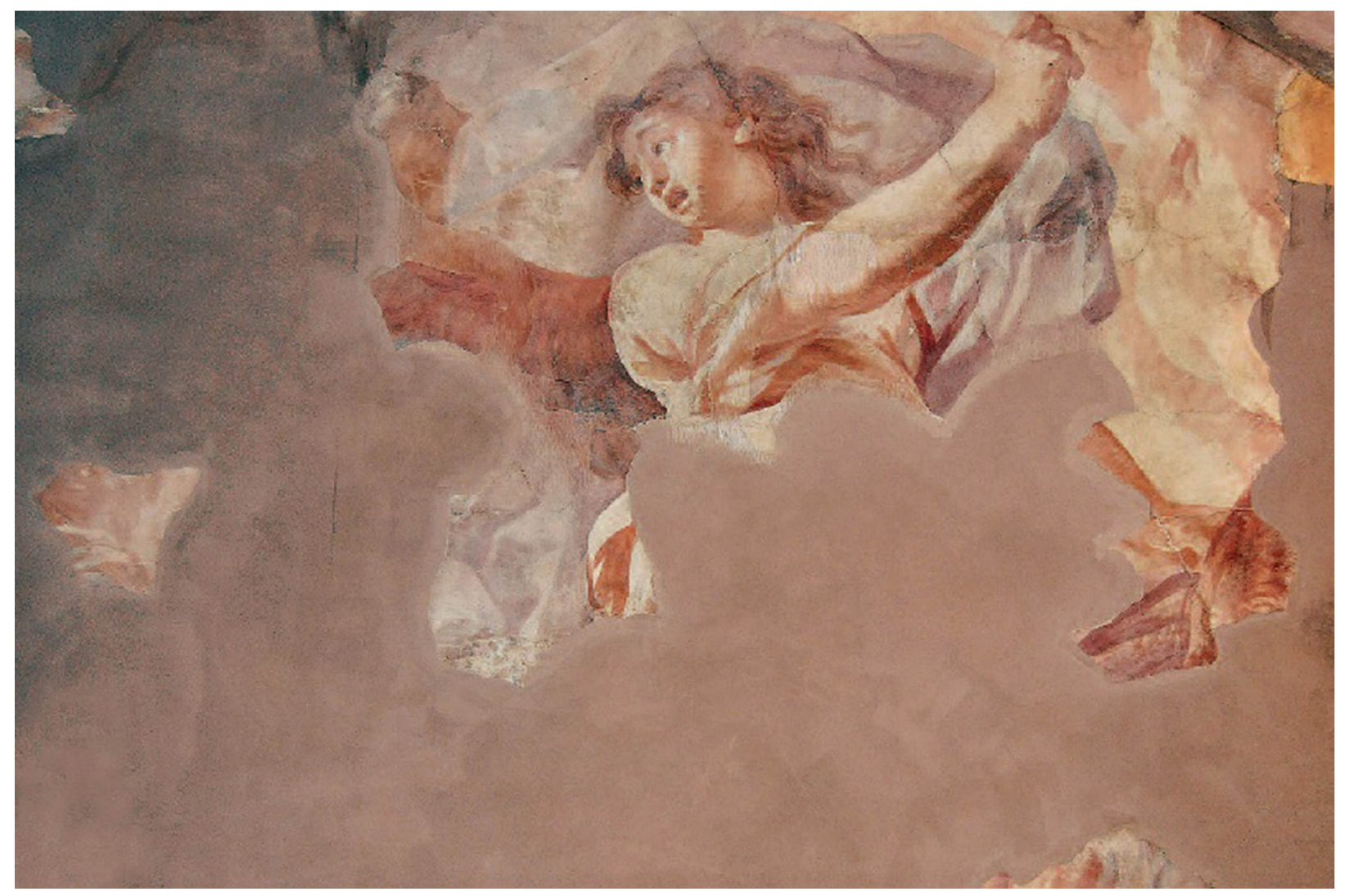

Şekil 9. Resimdeki tüm eksik alanlar için uygun bir nötr ton uygulanması (Weyer vd., 2015, s. 330). 
Nötr tamamlamada iki olasılık değerlendirilir,

-Resimdeki tüm eksik alanlar için uygun bir nötr ton uygulanması (Şekil 8),

-Resmin nispeten açık ve koyu alanları için her duruma uygun (Şekil 9) nötr ton uygulanmasıdır (Nicolaus, 1999, s. 291; Pascual ve Patino, 2003, s. 191).

Kusurlu bir alanı entegre etmek için doğru nötr rengi bulmak zordur ve her durumda bu, bir resmin genel etkisinin hem renk hem de form açısından değişikliğe uğramasına neden olur. Bir resmin şekli, nötr bir rötuştan da kesin olarak etkilenir. Her nötr rötuş düzlemseldir ve orijinal resmin bitişik uzamsal şeklini kendi formunun sınırları ile bozar. Çoğu durumda; nötr bir rötuş, bir resmin hem form hem de renk üzerindeki etkisini, standart veya toplam rötuştan daha radikal bir şekilde değiştirir (Nicolaus, 1999, s. 291). Tekniğin zorluğu ve ton altı uygulamasından farkı, uygulama öncesinde nötr rengin araştırılıp bulunmasıdır. Restoratörün renk konusunda tecrübeli olması ve öncesinde denemeler yapması gerekmektedir.

\subsubsection{Ton Altı}

Tratteggiodan türeyen diğer tekniklerden farklı olarak ton altı, tonal ayarlama ya da tonun düşürülmesi (Baroni, 2003, s. 149) olarak bilinen bir tekniktir13.

Teknik, eksik kısımlar için dolgunun beyazlığını azaltmak, tonaliteyi eşitlemek, özgün resimdeki aynı tonun hafif açığı ve soğuk olanına ulaşmayı amaçlar. Özellikle özgün resimdeki küçük ebattaki eksik kısımların parlak ve öndeymiş gibi görünmesini engellemek amaçlı ortaya çıkmıştır. Ton grimsi olabilir ve bu da özgün renklerin yanında arkasındaymış hissi verir. Hatta kayıp kısımlar özgün resmin içerisine dahil olan bir leke izlenimi verir (Mora vd., 1984, s. 307; Baroni, 2003, s. 150). Ton altı uygulaması yapılırken suluboya ile şeffaf tabakalar oluşturularak yapılan glazing tekniği ile birlikte, tratteggiodaki çizgiler, kısa çizgiler ve noktalama gibi farklı teknikler de tercih edilebilir.

Beyaz ve özgün resme göre parlak olan dolgu yapılmış boşluklar öncelikle mevcut rengin pigmentine uygun bir renk seçilerek glazing tekniği kullanılarak suluboya ile şeffaf tabaka oluşturulur. Şeffaf tabakalar mevcut özgün rengin tonundan daha düşük ton elde edilene kadar tekrar edilir. Tercihen noktalama ve/veya tarama kullanılarak mevcut renge bağlı olarak hafif soğuk ve/veya nötr tonlar ${ }^{14}$ eklenerek uzamsal olarak boşluğun hafifçe arkada görünmesi sağlanır (Şekil 10 ve Şekil 11).
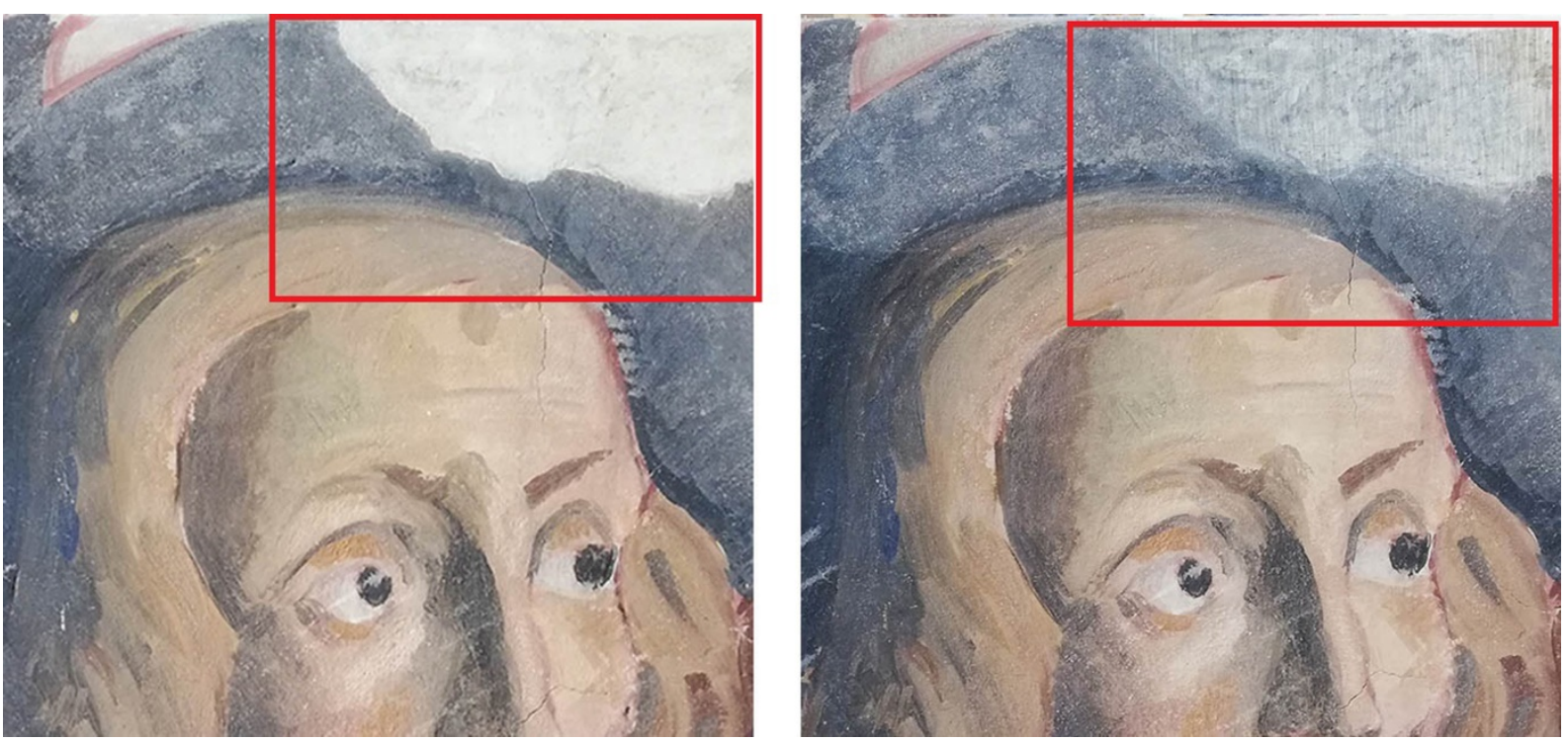

Şekil 10. Ton altı renk tamamlama uygulaması (soldaki öncesi ve sağdaki sonrası) (Yetiş, 2019).

Leonardo Da Vinci'nin Son Akşam Yemeği adlı duvar resminde ton altı tekniğinin oldukça detaylı ve başarılı bir kullanımı görülür (Sguaitamatti, 2012). Oldukça tahrip olmuş ve geniş alana yayılmış olan küçük ebattaki özgün resim tabakalarını birleştirirken hem figürlerin bütünlemesi hem de özgün kısımların ayırt

\footnotetext{
13 İtalyanca sottotono ve İngilizce undertone terimleri de teknik için kullanılan terimlerdir ve ton altı Türkçe karşılığı olarak tekniğin ișlevi ile bütünleşmektedir (Weyer vd., 2015, s. 336-337).

${ }^{14}$ Burada nötr tonlardan kastedilen siyah suluboya kullanımıdır. Suluboyalar şeffaflığa sahip olduğundan gri etkisi yaratacaktır.
} 
ediciliği sağlanmıştır (Şekil 12). Özellikle portre detaylarındaki eksik kısımlarda, mevcut renk ve tonun hafif açık ve soğuk olanı kullanılarak parlaklık azaltılmış ve hafifçe arkadaymış izlenimi oluşturulmuştur. Glazing ile birlikte titreşim yaratmadan noktalama ve tarama kullanıldığı görülmektedir.

Bu teknik ile resimlerdeki küçük kayıplarda, renk tonlarının devamlılığı sağlanarak, kolayca tamamlama yapılabilir. Aslında normal görüş mesafesinden yeniden yapılmış gibi görünebilirler, ancak yakın mesafeden kolayca öyle olmadı̆̆ı anlaşılabilir. Hassaslık gerektiren teknikte; boşluklar, orijinal resimle ya aynı seviyede ya da onun arkasındaymış gibi görünür (Mora vd., 1984, s. 307).

Bu tekniğe benzer Acqua Sporca ve Velatura teknikleri de bulunmaktadır.

Acqua Sporca (kirli su), genellikle potansiyel birliğin tehlikeye girdiği geniş ebattaki kayıpların rötuşu için alternatif bir teknik olarak kullanılmaktadır. Bu yöntem, etkilenen bölgeyi olabildiğince nötr bir renkle kaplamayı içermektedir (Murray ve Vazquez, 2010, s. 131; Napoleone, 2008, s. 22).

Velatura, özellikle ahşap panel resimlerinde boşluğu kaybolan rengin tonlarında rötuşlama tekniğidir. Bu durumlarda, orijinalden biraz daha açık bir renk tonu suluboya şeffaflığı ile tamamlanarak görünür bırakılır. Sivri veya kedidili firça ile uygulama yapılır (Baroni, 2003, s. 149).
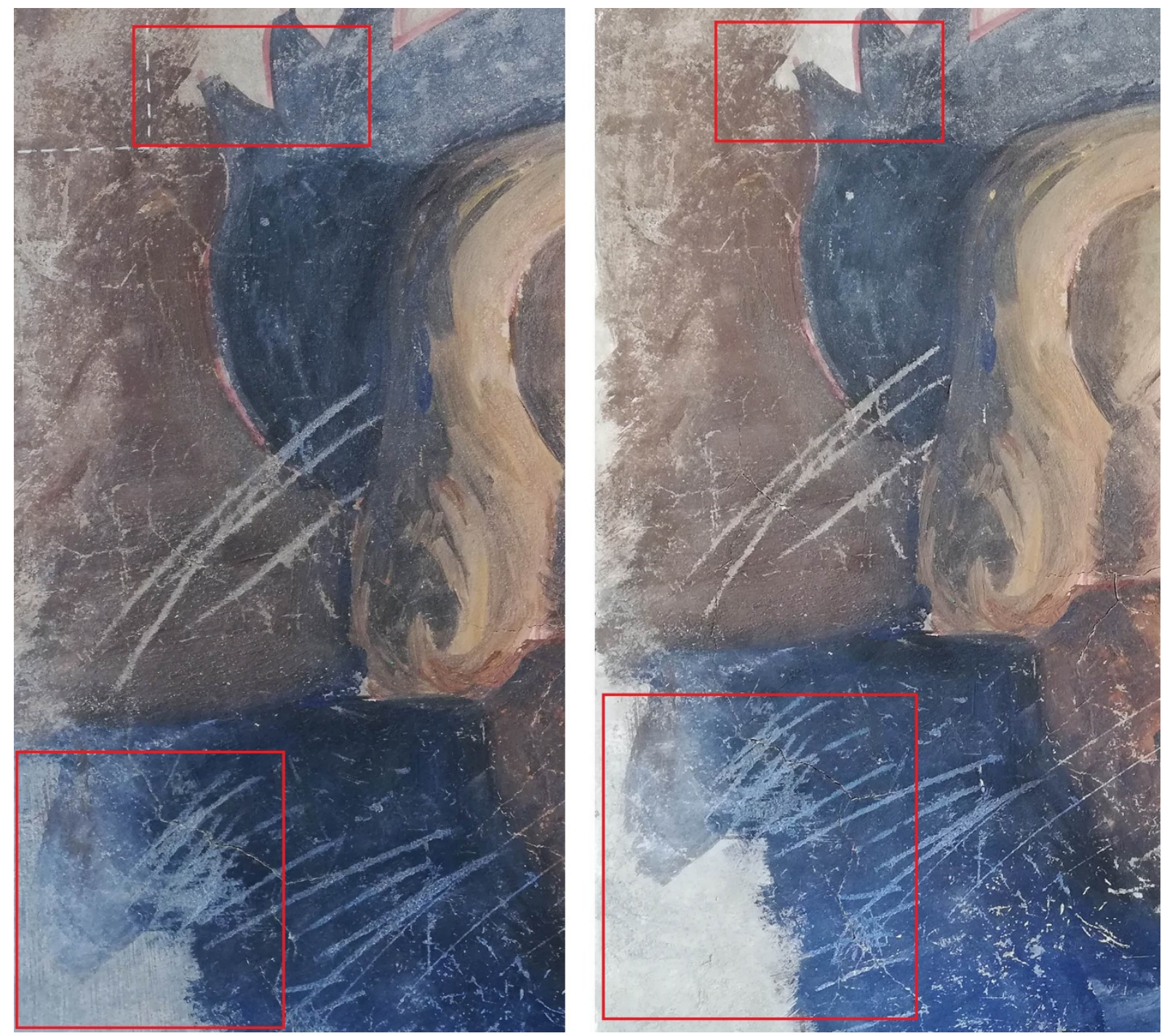

Şekil 11. Ton altı renk tamamlama uygulaması (sağdaki öncesi ve soldaki sonrası) (Yetiș, 2019). 


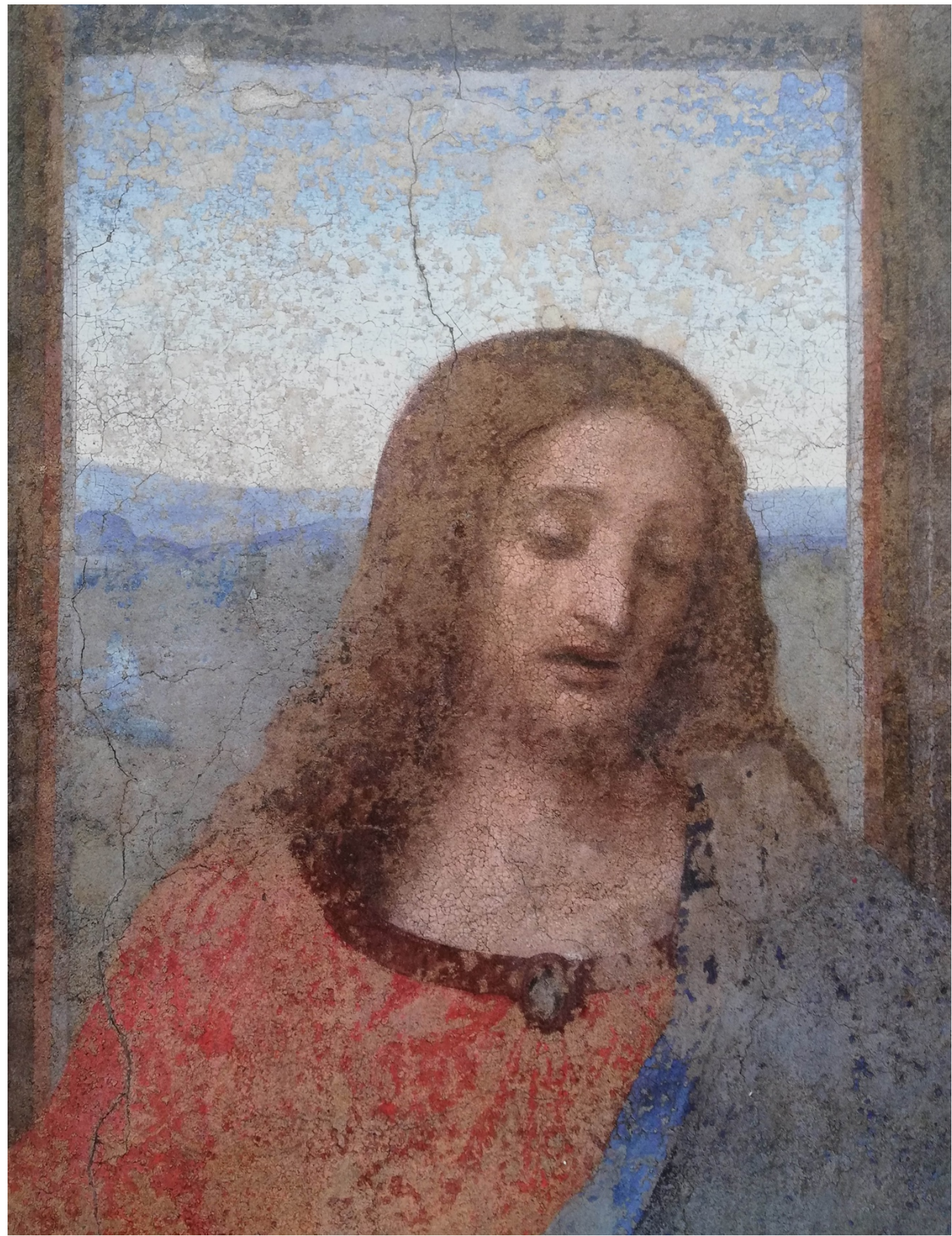

Şekil 12. Son Akşam Yemeği, Leonardo Da Vinci, 1490’lar (Sguaitamatti, 2012, s. 143).

\section{Değerlendirme ve Sonuç}

Renksel (resimsel) tamamlama, resmin eksilmiş alanlarında sanatsal ifadeyi ve ikonografik okunabilirliği arttırmak amacıyla farklı teknikler kullanılarak yapılan önemli bir koruma işlemidir. Günümüzde yapılmasına karar verilen bu uygulamaların sınırlı tutulması, orijinalinden ayırt edilebilir ve gerektiğinde geri alınabilir olması ilkesi önem kazanmıştır. 
Resim tamamlamalarında, korumanın diğer alanlarında olduğu gibi (Eskici, 2018, s. 135-153), farklı zamanlarda farklı ekollere bağlı olarak değişik yöntemler uygulanmıştır. Örneğin bazı Batılı restoratörler boşlukların fark edilmeyecek şekilde bütünlenmesini taklitçi/mimetik tamamlama; bazı İtalyan korumacıları ise tamamlamanın kesinlikle sınırlı ve orijinalinden açıkça ayırt edilebilir olması gerektiğini savunmuşlardır.

Geçmişte sanat eserlerinin özgünlük değeri çok dikkate alınmadan, estetik kaygılarla yapılmış olan taklitçi veya yoruma dayalı (hipotetik) tamamlamalar çoğu zaman sahte ve yanıltıcı sonuçlar doğurmuş; bu olumsuzlukların giderilmesi için bilhassa İkinci Dünya Savaşı sonrasında önem kazanan bilimsel restorasyon ilkelerinin gereği olarak, kuramsal temeli olan yeni yaklaşımlar benimsenmiştir.

Resimlerin artistik değerini ve ikonografik okunurluğunu arttırmak için yapılan renksel tamamlamaların sanat eserinin özgünlügüne saygıll, anlaşılabilir ve geri döndürülebilir olması gerekmektedir.

Bu doğrultuda resimlerdeki kayıp kısımlar 1940 yıllardan itibaren Brandi'nin öncülüğünde Gestalt kuramı bağlantılı olarak şekil-zemin ilişkisi bağlamında bütün olarak değerlendirilmiştir. Tamamlamalarda renk bilgisi içerisindeki eș zamanlı kontrastlık ve renk karışım metotları ile uzamsal ilişki oluşturularak, ayırt edicilik oluşturularak, rahatsız edici görünümün ortadan kaldırılması yoluna gidilmiștir.

$\mathrm{Bu}$ bağlamda, kayıp kısımların niteliğine bağlı olarak tercih edilen farklı teknikler geliştirilmiştir. Bu teknikler içinde kromatik seçim ve kromatik soyutlamanın tratteggio bağlantılı olarak geliştirildiği düşünülürse dört farklı tekniğin yaygın olduğu söylenebilir. Kromatik seçim yoruma sebebiyet vermeden tamamlanabilen, genellikle küçük ve orta ebattaki boşluklarda tercih edilmiștir. Kromatik soyutlama ise yorum yapılmadan tamamlanması güç olan boşluklarda çevre renklerin toplamıyla bağlantılı uygulanmıștır. Şekillerden bağımsız, sadece renklerle gerçekleștirilen bir uygulama söz konusudur. Ancak her ikisi de pratikte zaman alan uygulaması güç olan tekniklerdir. Özellikle tarama yapılırken restoratörün yeteneği önem arz etmektedir.

Nötr tamamlama tekniğinin taramanın zorluğuna alternatif olarak ve/veya geniş boşluklardaki rahatsız ediciliğin üstesinden gelmek için geliştirildiği söylenebilir. Özgün eserle bağlantılı olarak boşluğun ortalama tonu tercih edilmekle birlikte, şekle bağlı olarak farklı nötr tonların kullanımı da yaygındır. Ortalama tonun kullanımı kromatik soyutlama ile oldukça benzerdir, ancak burada tarama yapmak yerine renkler doğrudan uygulanır. Restoratöre düşen görev; kayıp kısımlar için, boşluğu hafif arkada gösterecek, doğru tinti (rengi) bulmaktır.

Her ebattaki boşluklarda kullanıldığı görülebilen ton altı uygulamasında mevcut renk ve tonun hafif açık ve soğuk olanı kullanılır. Böylece boşlukları nötr tonda olduğu gibi hafif arkada göstererek ayırt edicilik sağlanmaktadır. Bu doğrultuda tarama, noktalama ve glazing tekniklerinin kullanımına müsaade etmektedir. Renk/ton uygulama öncesinde karıștırılmadığı (hazırlanmadığı) için nötr tondan daha pratik ve hızlı bir tekniktir.

Kayıp kısımlardaki renk/tonun haricinde dolgunun dokusu (lustre), yüzey parlaklı̆gı (luminosite) ve boşluğun şekli bütüncül görsel algıyı değiştirmektedir. Dokulu bir yüzey ayırt ediciliği arttırırken, boşlukta rengin mat görünümüne sebep olacaktır. Özgün kısımlara göre boşluğun daha pürüzsüz ve parlak olması parlaklığı arttıracak ve boşluğun önde görünmesine sebep olacaktır. Özgün eserdeki boşlukların düzenli köșe dönüşlü veya girintili olması görsel algıyı değiștirecektir. Boşluğun şeklini değiştirme imkânı olmadığından renksel tamamlama yapılırken dikkate alınması gerekir.

Geçmişte gerçekleştirilen içeriği çarpıtılmış bazı yoruma dayalı veya taklitçi tamamlama uygulamalarıyla resimlerin belgesel ve görsel açıdan zarar görmeleri, günümüzde minimum müdahale diye adlandırılan koruma prensibinin benimsenmesini sağlamıştır. Bu doğrultuda, bilhassa arkeolojik alanlarda tahrip olmuș, bütünlüğünü kaybetmiş durumdaki duvar resimlerinde tamamlama yapılmayıp, mevcut kalıntıların oldukları gibi korunmaları görüşü önem kazanmıștır.

Sonuç olarak, rötuşun kurallarını belirlemek zordur ve her resim kurallarını kendi içinde barındırmaktadır. Her resim için ideal olan tek bir rötuş tekniği ve malzemesi bulunmadığı gibi, resim kendi şartları doğrultusunda değerlendirilmelidir. Burada uygulamayı yapan uzman konservatöre büyük sorumluluk düşmektedir. Uygulanacak kuramsal yaklaşım, teknik ve malzeme seçiminin kararı güvenilir bilgiye ve sanat tarihi, arkeoloji, koruma bilimi gibi alan uzmanlarının görüşüne dayandırılmalıdır. Uygulama öncesi denemeler yapılarak, yaratılan görsel algı titizlikle incelenmelidir. Konservatörün becerisi, hâkimiyeti ve tekniğin uygulanmasındaki yeteneği bu aşamada çok önemlidir. 


\section{Kaynakça}

Agulli, G. ve Silva, L. (2015). Treatment of lacunae, Gestalt psychology and Cesare Brandi. From theory to practice, A. Bailao, F. Henriques ve A. Bidarra (Ed.), 3rd International Meeting on Retouching of Cultural Heritage, RECH3 (s. 93-102) içinde, 23-24 October 2015, Porto, Portekiz.

Ahunbay, Z. (2009). Tarihi çevre koruma ve restorasyon. İstanbul: Yapı Endüstri Merkezi Yayınları.

Bailao, A. ve Calvo, A. (2015). The "value-function" attributed to cultural heritage as a criterion for reconstruction or reintegration: the paintings. A. Bailao, F. Henriques ve A. Bidarra (Ed.), 3rd International Meeting on Retouching of Cultural Heritage, RECH3 (s. 17-22) içinde, 23-24 October 2015, Porto, Portekiz.

Bailao A. ve Cardeira L. (2017). Mixing and matching. A survey of retouching materials. A. Bailao ve S. Sustic (Ed.), 4th International Meeting on Retouching of Cultural Heritage, RECH4 (s. 248-255) içinde, 2021 October 2017, Split, Hirvatistan.

Baldini, U. (1997). Teoria del restauro e unità di metodologia-2. Florence: Nardini Editore.

Baldini, U. (2001). Teoria del restauro e unità di metodologia-1. Florence: Nardini Editore.

Baroni, S. (2003). Restauro e conservazione dei dipinti: Manuale pratico. Milano: Fabbri Editori.

Botticelli, G. (2003). Metodologia di restauro delle pitture murali. Firenze: Centro Di.

Brandi, C. (1977). Teoria del restauro. Torino: Giuglio Einaudi editöre.

Brandi, C. (2005). Theory of restoration. Rome: ICR.

Briggs, D. (2012, Kasım). 6.1 Mixing paints. The Dimensions of Color. Erişim adresi: http://www.huevaluechroma.com/061.php

Briggs, D. (2015, Haziran). 11.2 Traditional and modern colour theory: 1 modern colour theory. The Dimensions of Color. Erişim adresi: http://www.huevaluechroma.com/112.php

Casazza, 0. (2007). Il restauro pittorico nell'unità di metodologia. Florence: Nardini Editore.

Conti, A. (2007). History of the restoration and conservation of works of art (H. Glanville, Çev.). Oxford: Butterworth-Heinemann.

Curtis, C., Anderson, S., Seims, J., Fleischer, K. ve Salesin, D. (1997). Computer-generated watercolor. Proceedings of the 24th annual conference on computer graphics and interactive techniques, SIGGRAPH '97 (s. 421-430) içinde. doi: 10.1145/258734.258896

Çağlar Eryurt, B. (2017). Ankara Devlet Resim ve Heykel Müzesi koleksiyonunda bulunan bir grup yağlı boya tuval resminin korunmasına yönelik araştırma ve uygulama çalışmaları (Yayımlanmamış doktora tezi). Gazi Üniversitesi Güzel Sanatlar Enstitüsü, Ankara.

Çağlar Eryurt, B. (2019). Yağlı boya tuval resminde mimetik tamamlama uygulaması [Tuval üzerine yağlıboya]. Berna Çağlar Eryurt fotoğraf arşivi, Ankara.

Çağlarca, S. (2018). Renk ve armoni kuralları. İstanbul: İnkılap Kitabevi.

Derksen, B. (2005). A white cup or two black faces? Wikipedia. Erişim adresi: https://en.wikipedia.org/wiki/Figure-ground_(perception)\#/media/File:

Cup_or_faces_paradox.svg

Doerner, M. (1984). The materials of the artist and their use in painting, with notes on the techniques of the old masters. San Diego: Harcourt Brace Jovanovich.

Efes yamaç evler duvar resimleri. (MS 100-300a). Tamamlama yapılmadan korunmuş duvar resmi [Sıva üzerine fresko ve sekko]. Bekir Eskici 2019 fotoğraf arşivi, Ankara.

Efes yamaç evler duvar resimleri. (MS 100-300b). 2,1 no'lu konut birimi 'tiyatro odasının' SR 6 kuzey duvarı tratteggio uygulaması [Sıva üzerine fresko ve sekko]. Berna Çağlar Eryurt 2019 fotoğraf arşivi, Ankara.

Ersen, A. (2011). Cesare Brandi (1906-1988) ve restorasyon teorisi. Restorasyon ve Konservasyon Çalışmaları Dergisi, 7, s. 3-11. 
Eskici, B. (2018). Seramik onarımlarında bütünleme yöntemleri üzerine bir değerlendirme. Sanat ve Tasarım Dergisi, 22, 135-153.

Genç, A. ve Sipahioğlu, A. (1990). Görsel algılama sanatta yaratıcı süreç. İzmir: Sergi Yayınevi.

Goethe, J. W. V. (2020). Renk öğretisi (İ. Aka, Çev.). İstanbul: Kırmızı Yayınları.

Gordon, E. (2000). A comparative study of Italian retouching techniques. J. Whitten (Ed.), AIC Paintings Specialty Group Postprints (s. 62-66) içinde, Pennsylvania: American Institute for Conservation of Historic and Artistic Works.

Grenda, M. (2010, Kasım). Tratteggio retouch and its derivatives as an image reintegration solution in the process of restoration. CeROArt [Online], EGG 1, doi: https://doi.org/10.4000/ceroart.1700

Hodge, S. (2016). Gerçekten bilmeniz gereken 50 sanat fikri (E. Gözgü, Çev.). İstanbul: Domingo Yayınları.

Hoeniger, C. (1999). The restoration of the Early Italian 'Primitives' during the 20th century: Valuing art and its consequences. Journal of the American Institute for Conservation, 38 (2), 144-161.

Itten, J. (1970). The elements of color (E. V. Hagen, Çev.). Ravensburg: Van Nostrand Reinhold Company.

Koffka, K. (1935). Principles of Gestalt psychology. Harcourt, Brace and Company. Erişim adresi: https://archive.org/details/in.ernet.dli.2015.7888

Mittone, L. (2010). The use of 'neutral colours' in the retouching of large losses in wall paintings. Erișim adresi: www.create.uwe.ac.uk/norway_paperlist/mittone.pdf

Mora, P., Mora, L. ve Philippot, P. (1984). Conservation of wall paintings. London: Butterworths.

Muir, K. (2010). Approaches to the reintegration of paint loss: theory and practice in the conservation of easel paintings. Studies in Conservation. 54 (1), 19-28.

Murray, N. ve Vazquez, E. (2010). Lacuna restoration: How to choose a neutral colour? Erişim adresi: http://www.cat.uab.cat/Public/Publications/2010/MuV2010/p131.pdf

Napoleone, L. (2008). Integrazione pittorica. Acqua sporca, sottotono, tinta neutra, rigatino. Progetto colore, $2,21-24$

Nicolaus, K. (1999). The restoration of paintings. Slovenia: Könemann.

Ocvirk, O.G., Stinson, R. E., Wigg, P.R, Bone, R. O. ve Cayton, D. L. (2015). Sanatın temelleri (N. B Kuru ve A. Kuru, Çev.). İzmir: Karakalem Kitabevi Yayınları.

Olsson, N. (2003). From mimetic to differentiated: Traditions and current practices in Italian inpainting. AIC Paintings Specialty Group Postprints (s. 4-12) içinde, Washington, DC: Textile Specialty Group of the American Institute for Conservation of Historic \& Artistic Works (AIC).

Opacity (optics) maddesi. (t.y.). Wikipedia içinde. Erişim adresi (22 Kasım 2020): https://en.wikipedia.org/wiki/Opacity_(optics)

Opak. (t.y.). TDK sözlükleri içinde. Erişim adresi: https://sozluk.gov.tr/

Öztuna, H. Y. (2008). Görsel iletişimde temel tasarım. İstanbul: Tibyan Yayıncılık.

Pascual, E. ve Patino, M. (2003). O restauro de pintura. Lisboa: Editorial Estampa.

Per, M. (2009). Başlangıcından İzlenimcilik'e kadar resimde rengin simgesel kullanımı. Yedi: Sanat, Tasarım ve Bilim Dergisi, (8), 17-26.

Seylan, A. (2019). Temel tasarım. İstanbul: YEM Yayınları.

Sguaitamatti, D. (2012). L'Arte rivelata dall'alta tecnologia L'Ultima Cena Leonardo Da Vinci. Milano: White Star.

Todorovic, D. (2008). Gestalt principles. Scholarpedia, 3(12), s. 5345. doi:10.4249/scholarpedia.5345

Weyer, A., Picazo, P. R., Pop, D., Cassar, J., Özköse, A., Vallet, J. M. ve Srsa, I. (Ed.). (2015). EwaGlos - European illustrated glossary of conservation terms for wall paintings and architectural surfaces. Almanya: Michael Imhof Verlag.

Yetiș, E. (2019). Ton altı renk tamamlama uygulaması [Sıva üzerine suluboya]. Ezgin Yetiş 2019 fotoğraf arşivi, Kastamonu. 
Yetiş, E. (2020a). Kromatik seçim renk tamamlama uygulaması [Sıva üzerine suluboya]. Ezgin Yetiş 2020 fotoğraf arşivi, Kastamonu.

Yetiş, E. (2020b). Kromatik soyutlama renk tamamlama uygulaması [Sıva üzerine suluboya]. Ezgin Yetiş 2020 fotoğraf arşivi, Kastamonu. 